\title{
An Organic Origin for the Carbonate Concretions of the Ohio Shale
}

\section{U.S. GEOLOGICAL SURVEY BULLETIN 1836}




\section{AVAILABILITY OF BOOKS AND MAPS OF THE U.S. GEOLOGICAL SURVEY}

Instructions on ordering publications of the U.S. Geological Survey, along with prices of the last offerings, are given in the current-year issues of the monthly catalog "New Publications of the U.S. Geological Survey." Prices of available U.S. Geological Survey publications released prior to the current year are listed in the most recent annual "Price and Availability List." Publications that are listed in various U.S. Geological Survey catalogs (see back inside cover) but not listed in the most recent annual "Price and Availability List" are no longer available.

Prices of reports released to the open files are given in the listing "U.S. Geological Survey Open-File Reports," updated monthly, which is for sale in microfiche from the U.S. Geological Survey, Books and Open-File Reports Section, Federal Center, Box 25425, Denver, CO 80225. Reports released through the NTIS may be obtained by writing to the National Technical Information Service, U.S. Department of Commerce, Springfield, VA 22161; please include NTIS report number with inquiry.

Order U.S. Geological Survey publications by mail or over the counter from the offices given below.

\section{BY MAIL}

\section{Books}

Professional Papers, Bulletins, Water-Supply Papers, Techniques of Water-Resources Investigations, Circulars, publications of general interest (such as leaflets, pamphlets, booklets), single copies of Earthquakes \& Volcanoes, Preliminary Determination of Epicenters, and some miscellaneous reports, including some of the foregoing series that have gone out of print at the Superintendent of Documents, are obtainable by mail from

\section{U.S. Geological Survey, Books and Open-File Reports Federal Center, Box 25425 Denver, CO 80225}

Subscriptions to periodicals (Earthquakes \& Volcanoes and Preliminary Determination of Epicenters) can be obtained ONLY from the

\section{Superintendent of Documents \\ Government Printing Ofrice \\ Washington, D.C. 20402}

(Check or money order must be payable to Superintendent of Documents.)

\section{Maps}

For maps, address mail orders to

\section{U.S. Geological Survey, Map Distribution \\ Federal Center, Box 25286 \\ Denver, CO 80225}

Residents of Alaska may order maps from

Alaska Distribution Section, U.S. Geological Survey,

New Federal Building - Box 12

101 Twelfth Ave., Fairbanks, AK 99701

\section{OVER THE COUNTER}

\section{Books}

Books of the U.S. Geological Survey are available over the counter at the following Geological Survey Public Inquiries Offices, all of which are authorized agents of the Superintendent of Documents:

- WASHINGTON, D.C.--Main Interior Bldg., 2600 corridor, 18 th and C Sts., NW.

- DENVER, Colorado--Federal Bldg., Rm. 169, 1961 Stout St.

- LOS ANGELES, California--Federal Bldg., Rm. 7638, 300 N. Los Angeles St.

- MENLO PARK, Callfornia--Bldg. 3 (Stop 533), Rm. 3128, 345 Middlefield Rd.

- RESTON, Virginia--503 National Center, Rm. 1C402, 12201 Sunrise Valley Dr.

- SALT LAKE CITY, Utah--Federal Bldg., Rm. 8105, 125 South State St.

- SAN FRANCISCO, California--Customhouse, Rm. 504, 555 Battery St.

- SPOKANE, Washington--U.S. Courthouse, Rm. 678, West 920 Riverside Ave.

- ANCHORAGE, Alaska--Rm. 101, 4230 University Dr.

- ANCHORAGE, Alaska--Federal Bldg, Rm. E-146, 701 C St.

\section{Maps}

Maps may be purchased over the counter at the U.S. Geological Survey offices where books are sold (all addresses in above list) and at the following Geological Survey offices:

- ROLLA, Missouri--1400 Independence Rd.

- DENVER, Colorado--Map Distribution, Bldg. 810, Federal Center

- FAIRBANKS, Alaska--New Federal Bldg., 101 Twelfth Ave. 


\section{An Organic Origin for the Carbonate Concretions of the Ohio Shale}

By R.E. CRISS, G.A. COOKE, and S.D. DAY 


\title{
DEPARTMENT OF THE INTERIOR DONALD PAUL HODEL, Secretary
}

\author{
U.S. GEOLOGICAL SURVEY
}

Dallas L. Peck, Director

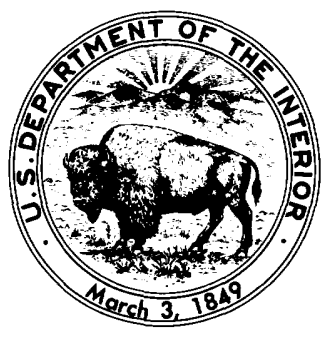

UNITED STATES GOVERNMENT PRINTING OFFICE: 1988

For sale by the Books and Open-File Reports Section, U.S. Geological Survey Federal Center, Box 25425, Denver, CO 80225

\section{Library of Congress Cataloging in Publication Data}

Criss, R.E.

An organic origin for the carbonate concretions of the Ohio Shale

(U.S. Geological Survey bulletin ; 1836)

Bibliography: $p$.

Supt. of Docs. no.: I 19.3:1836

1. Concretions-Ohio River Valley. 2. Rocks, Carbonate-Ohio River Valley.

3. Organic geochemistry-Ohio River Valley. 4. Ohio Shale. 5. Geology,

Stratigraphic-Devonian. I. Cooke, G.A. II. Day, S.D. III. Title.

IV. Series.

QE75.B9 no. $1836 \quad 557.3 s\left[552^{\prime} .5\right] \quad 87-600470$

[QE471.15.C58] 


\title{
CONTENTS
}

\author{
Abstract 1 \\ Introduction 1 \\ Acknowledgments 2 \\ Methods 3 \\ Field and petrographic relations 3 \\ Lithology and petrology 3 \\ Time of growth of the concretions 6 \\ Stratigraphic zonation of the carbonate concretions 9 \\ Isotopic and chemical relations 9 \\ Chemical composition 9 \\ Carbon and oxygen isotope data $\mathbf{1 2}$ \\ Interpretation of the $\delta^{13} \mathrm{C}$ values 13 \\ Interpretation of the $\delta^{18} \mathrm{O}$ values 14 \\ Discussion and conclusions 17 \\ References 18
}

\section{FIGURES}

1. Map showing outcrop belt of Devonian Shales in Ohio 2

2. Photographs of typical concretions from the Huron Member of the Ohio Shale near Worthington, Ohio 4

3. Schematic diagram showing mineralogical zonation in the concretions from the Huron Member of the Ohio Shale 6

4. Gray shale dike crosscutting the Huron Member of the Ohio Shale along the Huron River near Milan, Ohio 7

5. Concretions incorporated in clastic dike and sill complex, along the Huron River near Milan, Ohio 8

6. Graphs showing radial distribution of chemical contents and $\delta^{18} \mathrm{O}$ and $\delta^{13} \mathrm{C}$ values in concretions from Worthington, Ohio 10

7. Graph of $\delta^{18} \mathrm{O}$ vs. $\delta^{13} \mathrm{C}$ values of carbonate concretions from the Huron Member of the Ohio Shale $\mathbf{1 3}$

8. Photographs of concretions with fossil fish from several localities $\mathbf{1 5}$

\section{TABLES}

1. X-ray spectrochemical data for concretions from the Huron Member of the Ohio Shale 11

2. Isotopic composition of concretions from the Huron Member of the Ohio Shale, Worthington, Ohio 12

3. $\delta^{18} \mathrm{O}$ determinations of coexisting vug minerals in concretions of the Huron Member 13

4. Concretions from other localities-This study and others 14 


\title{
An Organic Origin for the Carbonate Concretions of the Ohio Shale
}

\author{
By R.E. Criss, ${ }^{1}$ G.A. Cooke, ${ }^{2}$ and S.D. Day ${ }^{3}$
}

\section{ABSTRACT}

Pyrite-rimmed carbonate concretions of the lowcarbonate Huron Member of the Ohio Shale are distinguished by their large size (to 3-m diam.), their high degree of sphericity, and their common association with the remains of arthrodire fish. Field relationships and the high ratio of authigenic to detrital components in the concretions indicate that they underwent rapid, early diagenetic growth as soft, low-density bodies that cemented the void space of extremely porous $(81<\Phi<94$ percent) sediment near the sediment-water interface. This early growth phase (stage 1) was probably associated with precipitation of small amounts of barite and whewellite and was followed by a protracted interval that featured (stage 2) formation of the pyrite rims and of small pyrite concretions, concurrent with compaction of the shale and with replacement of the concretions by calcite, followed by replacement of the calcite by $\mathrm{Ca}$ - and Fe-rich dolomite (except within the central zones of the largest concretions); (stage 3) formation of joints in the shale, followed by intrusion of clastic dikes, severe deformation of concretions incorporated in the dikes, and continued compaction of the shale; and (stage 4) complex recrystallization and replacement of the concretions, represented by partial dissolution and recrystallization of the calcite centers, growth of quartz, dolomite, and calcite in vugs and veins, and approximately concurrent growth of cone-in-cone layers in the shale. Oxygen isotope data $\left(-5.5<\delta^{18} \mathrm{O}<-2.5\right)$ of the dolomitic matrix of the concretions are consistent with the early rapid growth and replacement stages (1 and 2) occurring at low but progressively increasing temperatures in marine pore fluid. $\delta^{18} \mathrm{O}$ values of about -10 for recrystallized matrix calcite, most vug calcites, and a cone-in-cone layer suggest that stage 4 growth occurred at moderate temperatures (perhaps $75^{\circ} \mathrm{C}$ ) in the presence of marine pore fluid or, perhaps more likely, formation water that penetrated the shale at a later time. A noteworthy paradox is that, in the early portions of the proposed sequence, the highly porous, low-density $(0<1.5)$ sediment could seemingly not have

\footnotetext{
${ }^{1}$ U.S. Geological Survey, Reston, VA 22092.

${ }^{2}$ Dept. of Geological and Planetary Science, University of Pittsburgh, PA 15260.

${ }^{3}$ National Refractories and Minerals Corporation, Pleasanton, CA 94566.
}

hydrostatically supported the large, rapidly grown concretions, which now have $\rho \cong 3 \mathrm{~g} / \mathrm{cc}$. Furthermore, as is typical of carbonate concretions worldwide, the $\delta^{13} \mathrm{C}$ values of the carbonates are strikingly different from those of normal marine limestones but are similar to those of organic carbon and diagenetic carbonates. We demonstrate that the observed $\delta^{13} \mathrm{C}$ values are similar to those of fish-bearing concretions from several other marine sequences, and we propose, along with Berner (1968), that such concretions may have originated as bodies of adipocere (low-density organic soap) that formed rapidly during decay of proteinaceous matter in the sediment.

\section{INTRODUCTION}

The Upper Devonian Ohio Shale crops out along a north-south band through central Ohio (fig. 1). In the lower part (Huron Member) and upper part (Cleveland Member) of this black shale, there are several horizons that contain carbonate and pyrite concretions, as well as a few cone-in-cone layers. These large, unusual, and commonly fossiliferous concretions (fig. 2) were described by the earliest geologic investigators in Ohio, and several proposals were made for the conditions and causes of their formation. Much disagreement arose over the temporal relations of the concretions relative to the degree of compaction of the surrounding shale (Newberry, 1873; Daly, 1900; Westgate, 1926), although subsequently Clifton (1957) presented convincing arguments for their penecontemporaneous growth (see below). Other investigators focused on the chemistry and mineralogy of the black shale and made conflicting suggestions for the source of the organic matter, the postdepositional conditions that led to its preservation, and the environment of deposition (see summary by Hoover, 1960).

Studies of concretions from other localities and application of modern analytical techniques to concretions have greatly enhanced our understanding of these enigmatic bodies. Weeks (1957) demonstrated that fishbearing carbonate concretions from Colombia formed shortly after deposition of the sediment and proposed 


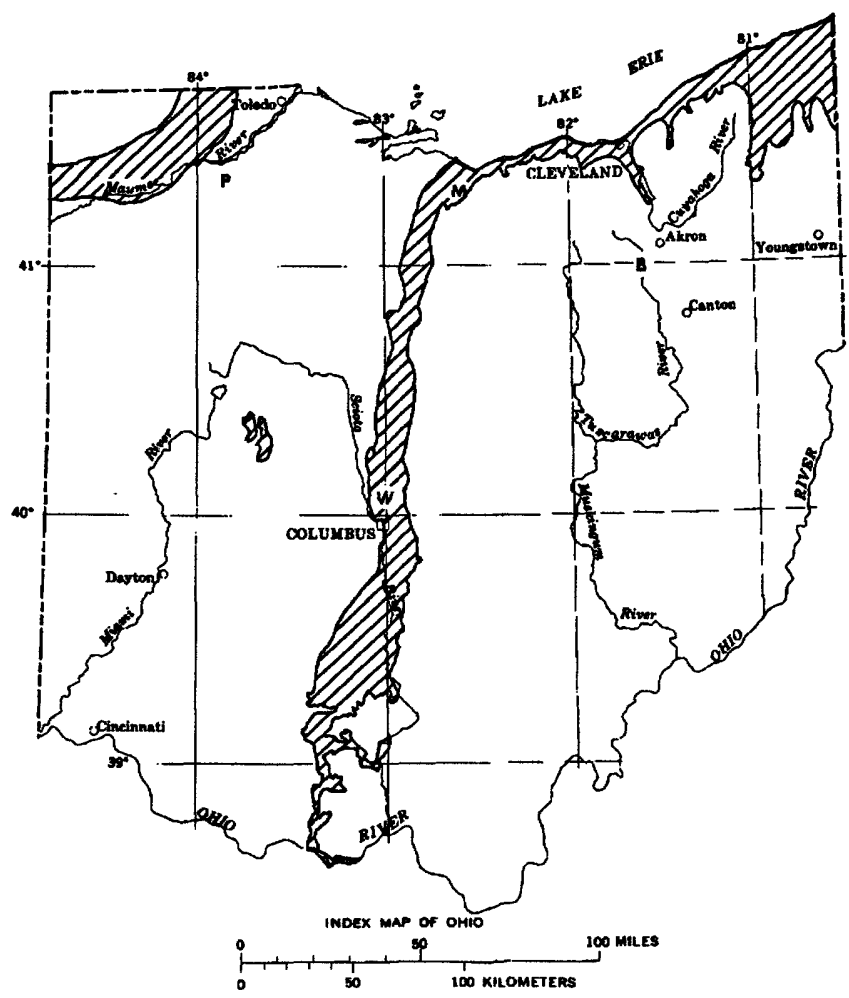

Figure 1. Map showing the outcrop belt of Devonian shales in Ohio, modified after Bownocker (1965). Localities discussed in text are as follows: W, Interstate 270 freeway cut in the Huron Member of the Ohio Shale at Worthington; $M$, cliff in Huron Member along Huron River near Milan; B, mine shaft at Barberton; P, Pugh Quarry in Devonian dolostone. Another sample was collected along the Interstate 71 freeway cut in the Cleveland Member of the Ohio Shale near Cleveland, Ohio.

that decay of proteinaceous material led to rapid precipitation of carbonate and hence to the remarkable preservation of the fossils. Lippmann (1955) proposed that the ratio of acid-soluble to acid-insoluble components in concretions may be used to estimate the sediment porosity at the time of concretion growth and argued that his results demonstrated extremely high porosities $(\Phi \cong 75$ percent) in some instances. Oertel and Curtis (1972) provided novel structural data that generally substantiate Lippmann's (1955) deductions, but they also presented evidence that a stage of slow, protracted growth followed the initial stage of rapid growth of their concretions. Girin (1967) and Galimov and others (1968) suggested that concretions preserve a sequential record of the diagenetic processes to which the host rock was subjected. Raiswell (1971) outlined criteria that distinguish the relative ages of diagenetic concretions.

Application of stable isotopic techniques to concretions has shed much new light on their origin and conditions of formation. Weber and others (1964) proposed that the $\delta^{13} \mathrm{C}$ values of siderite nodules are depen- dent on the environment of deposition of the enclosing sediment. The carbon isotopic data of Hodgson (1966) demonstrated that organic matter was typically involved in the formation of carbonate concretions, and his findings have had significant influence on recent models explaining concretion origin (Berner, 1968; Raiswell, 1976; Irwin and others, 1977). Although some concretions are known to form in freshwater environments (Degens and others, 1962), oxygen isotope data from carbonate concretions from numerous localities are similar to those of normal marine limestones and indicate that growth commonly occurred at relatively low but progressively increasing temperatures in marine pore fluid (Irwin and others, 1977; Coleman and Raiswell, 1981; Hennessy and Knauth, 1985). However, the common existence in such concretions of late-stage calcites that are rather strongly depleted in ${ }^{18} \mathrm{O}$ relative to normal marine limestones has led to varied interpretations, including substantial changes in pore fluid $\delta^{18} \mathrm{O}$ values during diagenesis (Coleman and Raiswell, 1981; also see Lawrence and Geiskes, 1981), or precipitation during subsequent incursion of meteoric water (Hudson and Friedman, 1976) or basin-derived connate water (Dix and Mullins, 1987), or a combination of all the above (Siegel and others, 1987).

This study attempts to determine the conditions of formation of the concretions of the Huron Member of the Ohio Shale and to determine how their character relates to the environment of deposition and to the subsequent diagenetic modification of the host shale. We direct particular attention to correlating concretion occurrence and growth to stratigraphic relations and to diverse stages that occurred during lithification of the enclosing shale. We also attempt to resolve the conditions of formation of late-stage vug and vein minerals in the concretions with $\delta^{18} \mathrm{O}$ measurements of coexisting phases (quartz and dolomite or calcite), and we compare these data with that of vug calcite from a well-known mineral-collecting locality in Devonian dolostone at Pugh Quarry, Wood County, Ohio. Our results also disclosed a need to test Berner's (1968) adipocere model for concretion growth, and we accordingly made a comparative stable isotope study of selected fish-bearing concretions from several other localities in the world.

\section{ACKNOWLEDGMENTS}

This study originated in 1972 as an undergraduate research project at Case Western Reserve University. Professors Samuel M. Savin and the late John Hower contributed abundant and much-needed advice and instruction. Elizabeth Kurowski, Mark Hower, Hsueh Wen Yeh, Thomas Durst, Matt Stairs, and Karl Criss provided instruction and assistance in the laboratory. We 
also thank M.E. Williams, the late D.H. Dunkle, and Virginia Heisey of the Cleveland Museum of Natural History for their valuable discussions and samples of fish-bearing concretions. S.M. Savin, J.R. O'Neil, Elliott Spiker, and W.L. Peterson made helpful critical comments. The Marathon Oil Company and the U.S. Geological Survey supplied financial support.

\section{METHODS}

Samples for $\mathrm{X}$-ray spectrochemical studies were preignited at $1100{ }^{\circ} \mathrm{C}$ and then fused with $\mathrm{Li}_{2} \mathrm{~B}_{4} \mathrm{O}_{7}$ (sample: flux ratio 2:1 by weight; Hower and others, 1964). Standards approximating the sample compositions were made from $\mathrm{Fe}_{2} \mathrm{O}_{3}$, silicic acid, $\mathrm{Al}_{2} \mathrm{O}_{3}, \mathrm{CaCO}_{3}$, $\mathrm{MgO}, \mathrm{KNO}_{3}$, and $\mathrm{TiO}_{2}$. Analyses were performed on a wavelength dispersive $\mathrm{x}$-ray fluorescence unit using standard methods. The analyzed elements are reported as oxides and are $\mathrm{K}, \mathrm{Ca}, \mathrm{Mg}, \mathrm{Al}, \mathrm{Ti}, \mathrm{Si}$, and $\mathrm{Fe}$ (reported as $\mathrm{Fe}_{2} \mathrm{O}_{3}$ ). Corrections were made for matrix absorption effects, but enhancement effects were assumed to be negligible (Hower and others, 1964).

Mineralogy of selected samples was determined using standard x-ray diffraction (Grim, 1968; Carroll, 1970) and petrographic techniques. The mineralogy of clays was determined on samples that had been acid washed and $\mathrm{H}_{2} \mathrm{O}_{2}$-treated to remove calcite and organic matter; oriented slides of the $<2 \mu \mathrm{m}$ material were then prepared by centrifugation. X-ray diffractograms were made of these slides before and after they were treated by $\mathrm{KCl}$ saturation, glycolation, and heating to $550^{\circ} \mathrm{C}$ and $650{ }^{\circ} \mathrm{C}$.

Carbon dioxide for mass spectrometic analysis was extracted from the calcite and dolomite of concretions by reaction with 100 percent phosphoric acid at $25{ }^{\circ} \mathrm{C}$ (McCrea, 1950). In most cases where both carbonates were present in the same sample, collection of the $\mathrm{CO}_{2}$ from each mineral was attempted by the method of Epstein and others (1964). Using the latter technique, $\mathrm{CO}_{2}$ from the predominant phase of the mixture is not significantly contaminated by that from the minor phase, but if the carbonates are not present in approximately equal proportions, the opposite is not true (Epstein and others, 1964). The matrix of the concretions in all cases comprises either calcite with minor dolomite or dolomite with minor calcite. The most accurate analyses will therefore be the "calcite cut" of a dominantly calcareous rock and the "dolomite cut" of a dolomitic rock; the complementary analyses of the minor phases are of lower reliability and are accordingly reported in brackets. The isotopic measurements have all been corrected using the method of Craig (1957), and are reported relative to the PDB standard (unless otherwise stated) in the usual delta notation. Following a recommendation by Land
(1980), no corrections have been made for the different acid-extraction fractionations of calcite and dolomite (Sharma and Clayton, 1965). Four $\delta^{18} \mathrm{O}$ analyses of quartz samples were made using the technique of Taylor and Epstein (1962) and are reported in table 3 relative to the SMOW standard. Precision is \pm 0.1 and \pm 0.2 per mil for the carbonate and the silicate analyses, respectively.

Most samples were collected from a roadcut along Interstate 270 about $2 \mathrm{~km}$ north of Worthington, Ohio. The locations of samples collected elsewhere are given in the text and tables (also see fig. 1).

\section{FIELD AND PETROGRAPHIC RELATIONS}

\section{Lithology and Petrology}

The Huron Member of the Ohio Shale is a grayishblack, fissile shale that generally contains pyrite and more than 10 percent organic matter (Hoover, 1960). Carbonized fossils of marine algae and terrestrial plants are common, but other fossils are notably scarce with the exception of conodonts and occasional brachiopods (Westgate, 1926; Wells, 1947). The rank of the shale in the area of study is rather low. Observed $\mathrm{H} / \mathrm{C}$ ratios in phytoclasts and Protosalvinia (Foerstia) from the Worthington locality are similar to those of high-volatile bituminous coals (Romankiw and others, in press). Conodont coloration ( $<1.5 \mathrm{CAI}$ ) also indicates a history of rather low temperature conditions in the upper Devonian rocks of central Ohio (Epstein and others, 1977).

Nelson (1955) determined that the dominant mineralogy of the Huron Member is quartz, illite, and chlorite, and that kaolinite is normally absent. Hosterman and Whitlow (1983) report that, in drill holes representing a large area of the Appalachian basin, the lower unit of the Huron Member has an average composition of 25 percent quartz silt, 15 percent chlorite, 60 percent illite, 20 percent mixed-layer illite-smectite, 5 percent kaolinite, and a trace of mixed-layer illite-chlorite. However, kaolinite was found in only about half the samples, being most abundant within and east of eastern Ohio and, accordingly, indicating an eastern and northeastern source for this detrital clay (Hosterman and Whitlow, 1983). Our $x$-ray diffractograms of the shale at Worthington generally confirm these results, but our observations of a continuous spectrum between $10 \AA$ and $14.4 \AA$ suggest that mixed-layer illite-chlorite is more abundant. We did not observe significant changes of this material on glycolation, on heating to $550{ }^{\circ} \mathrm{C}$, or on saturation with $\mathrm{KCl}$. Carbonate minerals were not detected in our x-ray study of untreated shale samples except in regions adjacent to concretions. We also found that the clay fraction from the center of the large concretions is 
Figure 2. Photographs of typical concretions from the Huron Member of the Ohio Shale near Worthington, Ohio. A. Concretion from the Huron Member, Interstate 270 cut, Worthington, Ohio, broken along the stratification plane through centerline. Dark, angular material in center is an arthrodire plate (apatite). Enclosing material is predominantly calcite spar (lightcolored inner zone), in sharp contact with surrounding, weathered, ochrecolored dolomite zone. Most concretions also have a thin $(<1-\mathrm{cm}$ thick) pyrite rim. B. Huron Member concretion, approximately $1 \mathrm{~m}$ in diameter, broken in vertical section. Note the irregular but sharply defined boundary between the light-colored calcite zone and the surrounding dolomite zone, which formed by replacement. Also note that the calcite zone, although bounded laterally, extends from the top to the bottom of the concretion. C. Huron Member concretion, about $1.5 \mathrm{~m}$ in diameter, at the Narrows near Worthington, Ohio. Note the stratification planes passing through the concretion. Shale layers are wrapped around the concretion due to differential compaction, as discussed in the text. $D$. Typical concretion in the Huron Member, Interstate 270 freeway cut, Worthington, Ohio. Painted, 5-foot $(1.5-\mathrm{m})$ rod shows scale. Note the ellipsoidal form, the stratification planes passing through concretion, and the "funnel-shaped" depression in top. $E$. Small dolomitic concretions from the Huron Member at Worthington, Ohio. One sample has been broken to reveal the rim of radially oriented pyrite crystals. $F$. Unusually large pyrite concretion from the Huron Member at Worthington. Note that the bedding in the shale, highlighted by pyrite, can be readily traced into the granular pyrite zone that constitutes the interior of the concretion. Also note the decreased width of the layers peripheral to the concretion (as compared to the inside), and the well-developed, symmetrical compaction features in the shale peripheral to the concretion. All these features indicate preservation of original pore space by concretion formation during progressive compaction of the sediment (see text). However, the perimeter of the concretion comprises larger, euhedral, radially oriented pyrite crystals that incorporated little or no sediment, but rather displaced it mechanically. Sample is $12 \mathrm{~cm}$ long.
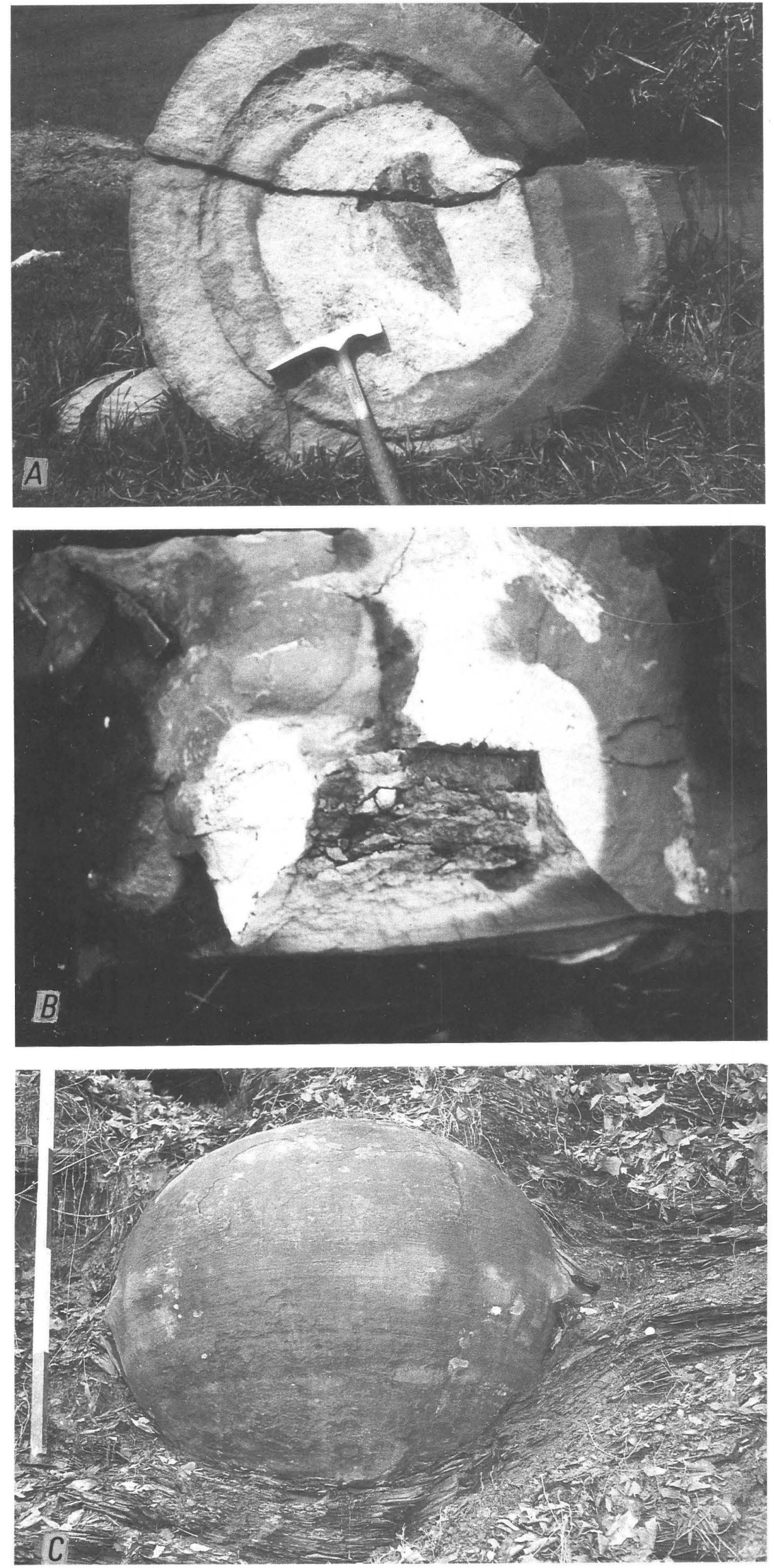

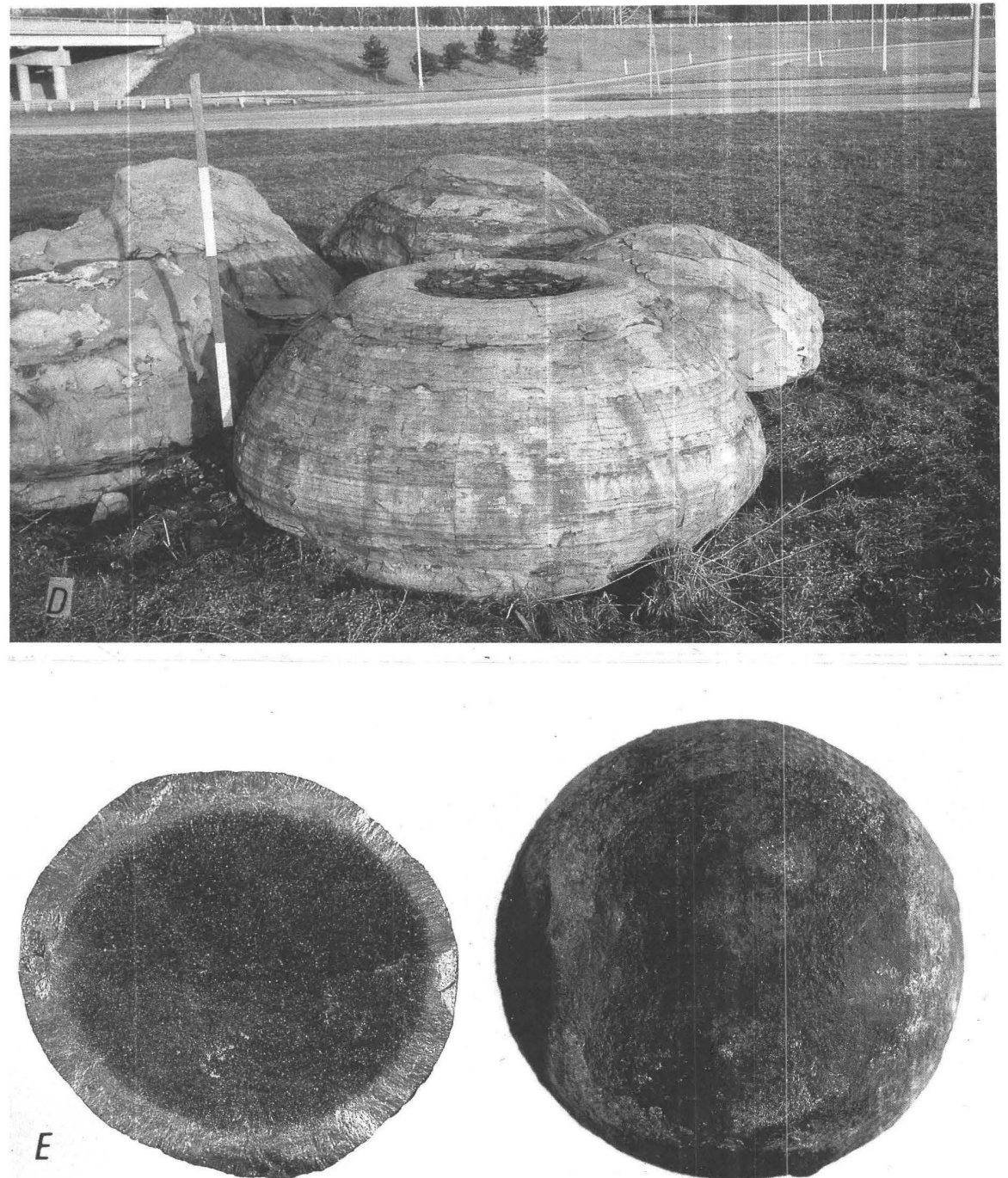

|

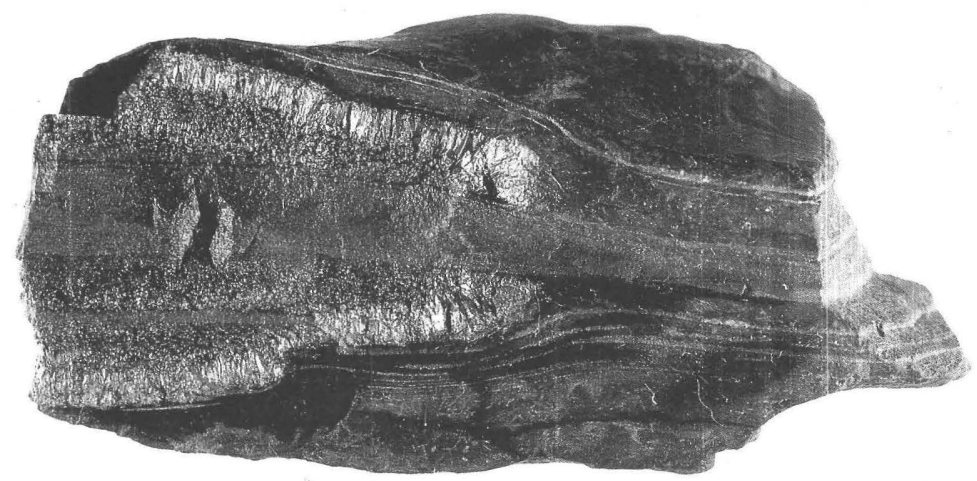




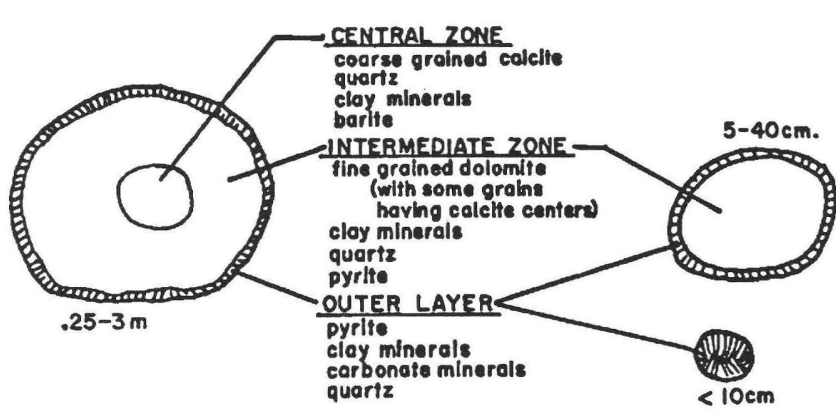

Figure 3. Schematic diagram showing mineralogical zonation in the concretions from the Huron Member of the Ohio Shale. Compare figures $2 A, 2 E$, and $2 F$.

mineralogically similar to that of the shale, except that the $7.2 \AA / 10 \AA$ peak-height ratio is somewhat larger in the concretion clays.

The large (0.25- to 3-m diam) concretions are nearly spherical, with minor elongation along the horizontal axis, and are composed primarily of calcite, dolomite, quartz, pyrite, barite, clay minerals, and organic matter (Westgate, 1926; Hoover, 1960; see fig. 2). "Funnel-shaped" depressions occur at the tops and bottoms of some concretions (Newberry, 1873; Clifton, 1957; fig. $2 D$ ). Veins and vugs in the concretions are most commonly lined with calcite and less commonly contain dolomite or quartz; pyrite and barite are not present in these late-stage features. Selenite (gypsum; Stauffer and others, 1911), fluorite and celestite (Clifton, 1957), and fine-grained magnetite (Cooke, 1976) have also been reported in the concretions. Hyde and Landy (1966) reported whewellite $\left(\mathrm{CaC}_{2} \mathrm{O}_{4} \cdot \mathrm{H}_{2} \mathrm{O}\right)$ in the concretions at Milan, Ohio, and we found this oxalate mineral in one concretion at Worthington. Fossils of arthrodire plates (fig. $2 A$ ) and terrestrial plants commonly occur in the centers of the concretions (Newberry, 1873). Foreman (1959) reported that some concretions contain abundant, well-preserved radiolaria.

We observe three distinct mineralogical zones with abrupt boundaries in the large concretions (figs. $2 A, 2 B, 3$ ). The central zone is predominantly ( $>60$ weight percent) coarse-grained $(\cong 1 \mathrm{~cm})$ calcite, with quartz, clay minerals, and small amounts of barite and pyrite. This barite occurs either as clear euhedral crystals or as dendritic forms that are completely enclosed within and are probably replacing the matrix. These barite crystals probably originated in the rapid growth stage or in the earliest part of the subsequent replacement stage (see below). This center is surrounded by an intermediate zone that is more than 80 weight percent finegrained $(\cong 0.1 \mathrm{~mm})$ dolomite with appreciable pyrite, quartz, clay minerals, and minor calcite (Westgate, 1926). This zone commonly has a weak radial structure, which, together with relict stratification planes in the concretion (see below), defines planes of weakness along which cracks and joints preferentially develop. Most concretions also have a thin $(<2-\mathrm{cm}$ thick) outer layer comprising radially oriented pyrite crystals within a claycarbonate matrix. Exterior to the concretions there is generally an indistinct zone of dolomite-cemented shale that grades continuously into the carbonate-poor shale. Large (up to $10 \mathrm{~cm}$ long) euhedral crystals of barite, as well as our single whewellite sample, were found in this indistinct zone, which is principally developed as an annular "girdle" (pressure shadow?) about the concretion centerline. These barite crystals are again completely enclosed by the shaley matrix material and are commonly outlined by pyrite. We found delicate calcite boxworks of the cleavage cracks of former, large barite crystals in some concretions. Clifton (1957) reports that cone-incone structure occurs in the peripheral zone of some concretions.

Small (5 to $25 \mathrm{~cm}$ diam) concretions in the Huron Member consist only of the dolomitic "intermediate" zone with an exterior shell of pyrite; also present are small ( $<10 \mathrm{~cm}$ diam), slightly ellipsoidal to disc-shaped concretions composed almost entirely of pyrite and shale components (figs. $2 E, 2 F, 3$ ). In a few cases we found both types of these small concretions enclosed within the outer parts of the dolomite zone of large concretions, a relationship indicating partial temporal overlap of the growth of large and small concretions.

Several lines of evidence indicate that the dolomite zones were formed from preexisting calcite by replacement. The boundary between the central and intermediate zones of the large concretions is extremely sharp and therefore consistent with replacement. This boundary is nearly circular along horizontal sections through the concretions (fig. $2 A$ ) but is rather irregular and elongate on vertical sections (fig. $2 B$ ), commonly extending to the "funnel-shaped" depressions that commonly occur at the top and bottom of the concretions. This shape clearly indicates that the calcite core zones are remnant, having been replaced by dolomite at a stage when sufficient compaction had ensued to produce significant anisotropy in the permeability of the shale. Stained thin sections provide equally clear-cut evidence for replacement in that the dolomite grains of the intermediate zone often have centers of calcite. The replacement of calcite by dolomite might be associated with superimposed, more reducing conditions that are evidenced by the pyrite rims, insofar as dolomite formation is strongly inhibited by aqueous sulfate (Baker and Kastner, 1981).

\section{Time of Growth of the Concretions}

The temporal relations of the concretions in the Huron Member of the Ohio Shale were first investigated 
by Newberry (1873), who noted the pronounced arching of the shale above and below the concretions (fig. $2 C$ ). Newberry (1873) reasoned that the concretions formed in incompletely consolidated sediment, and that the arching resulted from subsequent compaction that deformed the sediments but not the rigid concretion. Daly (1900) noted similar arching of shale around the carbonate concretions at Kettle Point, Ontario, but proposed that the fully compacted shale had been deformed during epigenetic growth of the concretions. Stauffer and others (1911) noted that the bedding planes of the shale could commonly be traced into the concretions, and Westgate (1926) observed that the width between any two such bedding planes increases from the edge to the center of the concretions (fig. $2 F$ ). Westgate (1926) proposed that these layers had been physically pushed apart during the deposition of the concretionary material; thus his view is similar to Daly's (1900). Clifton (1957) concluded that concretion growth was penecontemporaneous, reasoning that compaction of the sediments progressed as the concretions grew outward and filled the pore space. According to Clifton's (1957) hypothesis, the width between enclosed bedding planes would progressively decrease from the center to the periphery of the concretion; eventually, when growth stopped, the shale would warp around the concretion as suggested by Newberry (1873).

Several independent lines of evidence support the interpretations that Newberry (1873) and Clifton (1957) advanced for the Huron Member concretions. First, Clifton (1957) noted that uncrushed Tasmanites occur in the concretions but not in the shale, and Foreman (1959) made similar observations about radiolaria. Second, our chemical data demonstrate that a significant shale component is present within the concretions and that the fractional amount of this component increases radially outward in the concretions, as described below. Furthermore, the high porosities indicated by our data ( 81 to 94 percent) are in accord with observed values for recent uncompacted argillaceous muds (generally 70 to 90 percent; Müller, 1967).

In addition, we found several small, rotated and sometimes severely crushed, pyrite-rimmed, Huron Member-type concretions in a clastic dike near Milan, Ohio (figs. 4,5). This unique locality permits many important temporal relations to be discerned. Part of the dike occupies joints with the same NE orientation as the principal joint set in the area (fig. 4). However, a major offshoot of the dike is nearly concordant with the enclosing black shale; note that the joints in the black shale do not cut the clastic intrusion (fig. $5 A$ ). The intrusive material is lithologically similar to the light grey shale (Olentangy Shale?) that underlies the Huron concretionary zone. In one case the dike material is visibly warped around a concretion (fig. $5 C$ ), indicating that joint for-

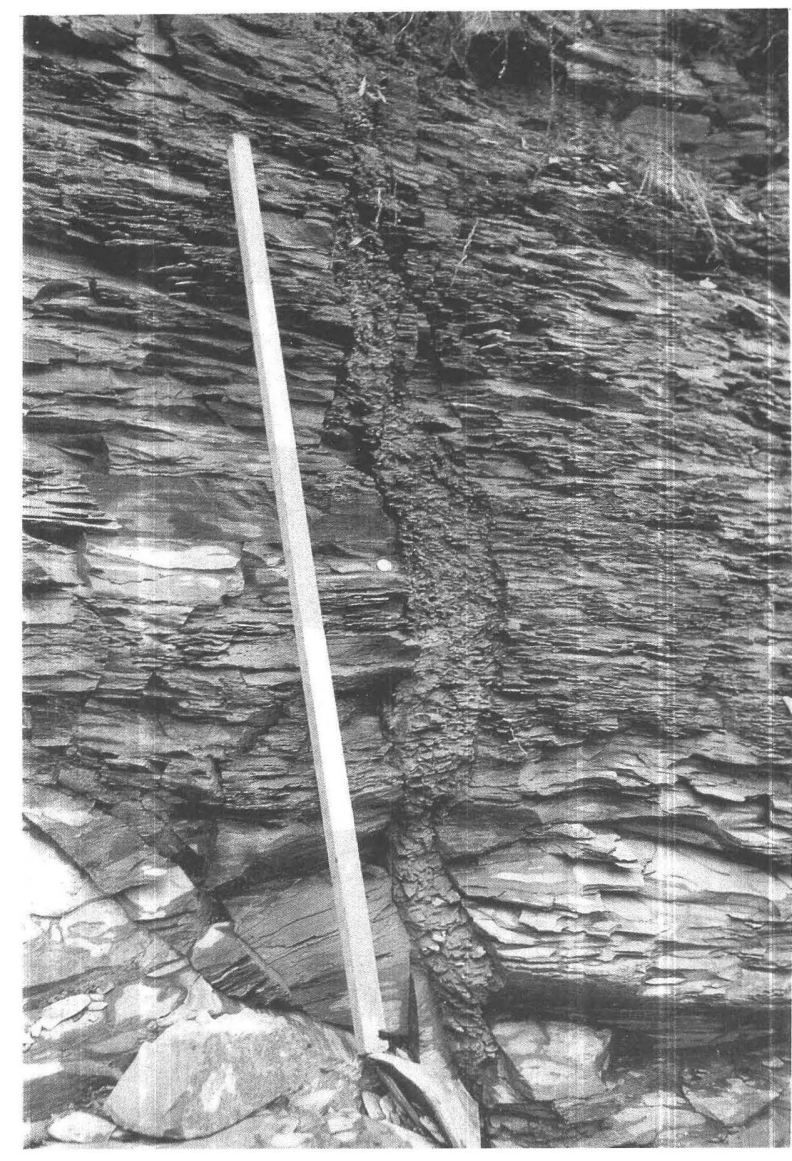

Figure 4. Gray shale dike crosscutting the Huron Member of the Ohio Shale along the Huron River near Milan, Ohio. This part of the dike occupies one of the prominent, NE-trending joints in the host black shale; however, a major sill-like offshoot of the dike (not shown) is only locally, but clearly, discordant. The dike and sill complex contains fragments of the black shale as well as small, rotated and deformed, pyrite-rimmed concretions (see fig. 5).

mation and intrusion occurred before compaction was complete. The concretions were obviously formed before their incorporation in the dike, and thus the warping could not be the result of concretionary growth. Severe deformation of most of the concretions in the dike (fig. $5 A, 5 B)$ indicates that they still retained some degree of their inferred initial soft character; moreover, their deformable nature was apparently retained (1) after the pyrite rims were formed, and (2) after much of the matrix material had become, or was destined to become, dolomite. Even so, the density of the concretions at that time probably exceeded that of the intrusive material, insofar as at least one specimen (fig. $5 \mathrm{C}$ ) had sunk to the bottom of the subhorizontal part of the dike. Calcite overgrowths occur on several of these incorporated concretions (fig. $5 B)$.

On the other hand, there is also some petrographic evidence for small-scale, mechanically displacive growth 

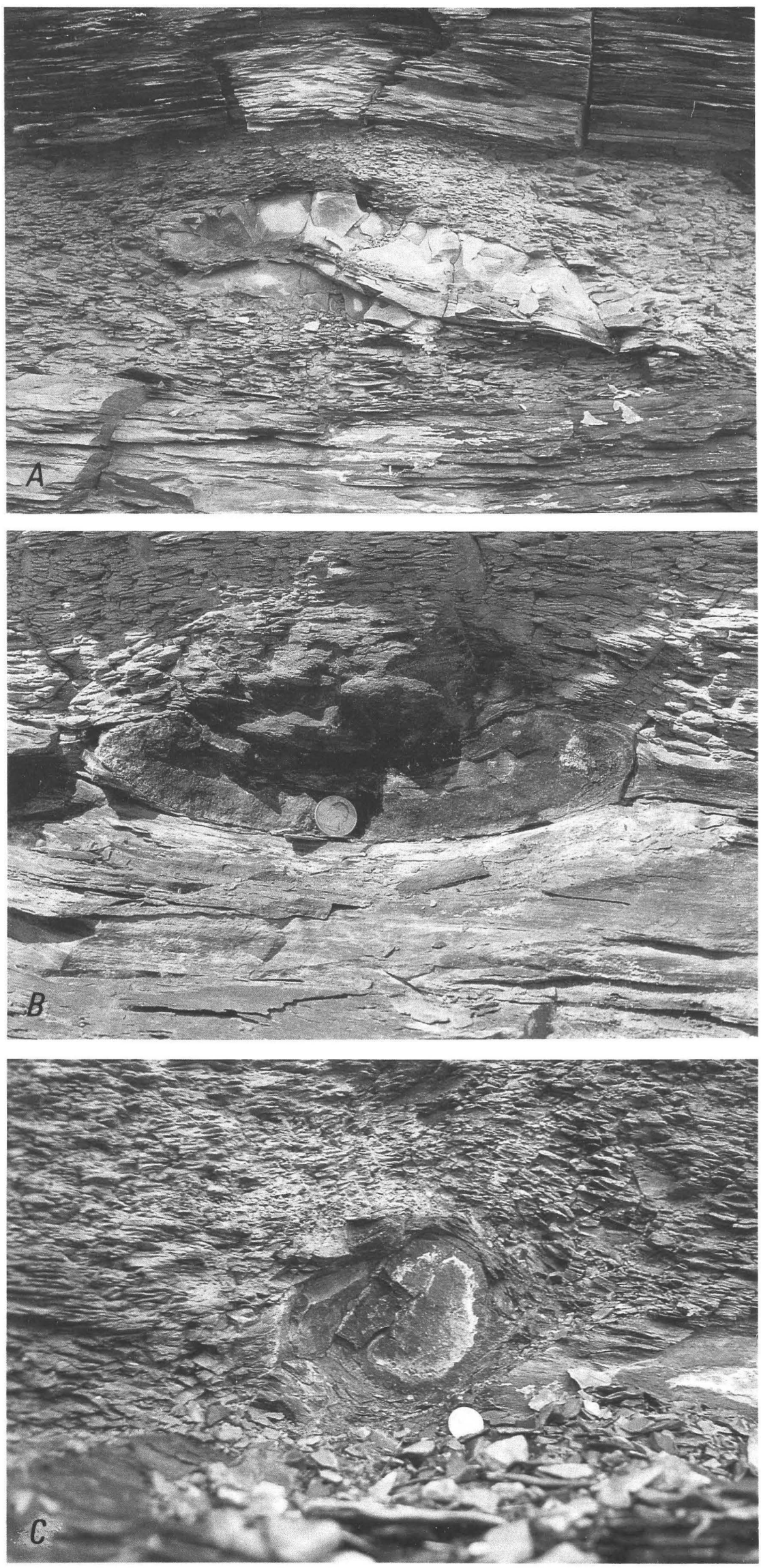

Figure 5. Concretions incorporated in clastic dike and sill complex, along the Huron River near Milan, Ohio. A. Highly deformed, 50-cm-long concretion within sill-like part of clastic dike. Note that the prominent, nearly vertical joints in the black shale do not cut the intrusive material. B. Highly sheared (U-shaped), pyrite-rimmed dolomitic concretion at lower interface of clastic sill and host black shale. A prominent calcite overgrowth occurs along the concave part of the concretion perimeter. Quarter dollar shows scale. C. Rotated, slightly deformed, pyrite-rimmed dolomite concretion in clastic sill. Weak, differential compaction features are developed in the dike peripheral to the concretion. This concretion appears to have sunk to the bottom of the sill. Quarter dollar shows scale. 
of authigenic minerals. Examples are the large, perfectly clear, barite crystals within and immediately outside the concretions, and the euhedral, $1-\mathrm{cm}$ pyrite crystals on the outside of some small concretions (fig. $2 F$ ). Cone-in-cone layers in the formation provide another example of possible displacive growth (Brown, 1954). It is therefore reasonable to infer that at least some displacive growth occurred in the Huron Member concretions, and this might partly explain why the "porosities" calculated from our chemical data are so high (also see discussions in Raiswell, 1971, and Hennessy and Knauth, 1985).

\section{Stratigraphic Zonation of the Carbonate Concretions}

Several workers have noted that the large carbonate concretions tend to occupy definite stratigraphic horizons that generally occur in the lower part, perhaps the lowermost 10 to $30 \mathrm{~m}$, of the Huron Member of the Ohio Shale (Newberry, 1873). This feature led Westgate (1926) to suggest that channelized fluid circulation above the underlying "impervious" Olentangy Shale played a role in concretion development. However, all the original observations were made along the extensive Devonian outcrop belt in Ohio and do not necessarily have any bearing on the distribution of concretions in the subsurface to the east, insofar as the outcrop belt is approximately parallel to the original shoreline (Barrell, 1913). If the concretions always occur near the base of the Huron Member, then the concretions occupy a diachronous stratigraphic zone, because the Ohio Shale is widely regarded to be part of a transgressive sequence related to the Catskill delta (Barrell, 1913; Allen and Friend, 1968; Schwietering, 1977; Dennison and Textoris, 1977). However, a comparison of the concretionary horizons with a biostratigraphic zone suggests that the concretions occupy an interval that is at least approximately synchronous.

Studies by Hass (1956), Winslow (1962), Winder (1966), Schopf and Schwietering (1970), and Murphy (1973) have established that a relatively thin $(<45-\mathrm{m}$ thickness) Foerstia zone occurs at widely distributed localities in the Huron Member (Ohio and Kentucky), Chattanooga Shale (Tennessee), Chagrin Shale (Ohio), Kettle Point Shale (Ontario), and Ellicot Shale (Pennsylvania and New York). Where comparisons are possible, the published descriptions indicate that the carbonate concretions occur near and not more than $30 \mathrm{~m}$ below the base of the Foerstia zone (see Hass, 1956; Winder, 1966; Schopf and Schwietering, 1970; also see figure 6 of Broadhead and others, 1980). Unfortunately, the presence or absence of the concretions east of the Devonian outcrop belt cannot be inferred from drill-hole data. However, Stauffer (1944) noted large (to 0.6-m diam) carbonate concretions in a 670-m-deep mine shaft at Barberton, Ohio, approximately $90 \mathrm{~km}$ downdip from the outcrop belt (see fig. 1). The latter concretions occur

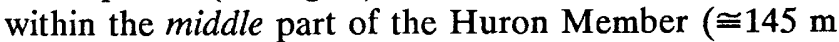
above the base), and none were described in lower levels of the formation (Stauffer, 1944). Furthermore, the Barberton concretions occur only $\cong 30 \mathrm{~m}$ below the base of the Foerstia zone identified by Hass (1956) and Winslow (1962). Thus, the available evidence suggests that the large carbonate concretions have a much closer spatial relationship to the presumably synchronous Foerstia zone than to the diachronous base of the Huron Member. This evidence implies that a temporal factor, perhaps a decrease in the rate of sedimentation, or large-scale stagnation of bottom waters, is responsible for the stratigraphic distribution of the carbonate concretions.

\section{ISOTOPIC AND CHEMICAL RELATIONS}

\section{Chemical Composition}

$\mathrm{X}$-ray spectrochemical analyses made of samples from traverses across two large concretions (fig. 6) are given in table 1. Also included are wet chemical analyses of a concretion and a shale sample from the Huron Member of the Ohio Shale (Westgate, 1926) that for comparison purposes have been recalculated to 100 percent for the indicated constituents. The analyses generally confirm that the concretions consist predominantly of carbonate minerals and shale constituents, and they clearly demonstrate the chemical zonation of the bodies. Because volatile constituents were not determined (except by Westgate, 1926), mineralogic interpretation of the oxide concentrations can be made only in conjunction with petrographic data.

Analyses of three central zone samples (T3A-1, -2 and $\mathrm{T} 3 \mathrm{C}-1$ ) indicate a predominance of calcite, but the high $\mathrm{SiO}_{2}: \mathrm{Al}_{2} \mathrm{O}_{3}$ ratios suggest that authigenic quartz is present. Most of the iron reflects the presence of pyrite, and the clay-related oxides $\left(\mathrm{Al}_{2} \mathrm{O}_{3}, \mathrm{~K}_{2} \mathrm{O}, \mathrm{TiO}_{2}\right)$ represent shale components incorporated in the concretion.

Our analyses of six samples from the "intermediate zone" (T3A-3, $-4,-5$ and T3C-2, $-3,-4$ ) agree closely with the concretion analysis by Westgate (1926), and all are significantly different from those of the central zone. The markedly greater $\mathrm{MgO}$ and $\mathrm{Fe}_{2} \mathrm{O}_{3}$ contents primarily reflect the presence of ferroan dolomite and a radial increase in pyrite. Westgate's (1926) complete chemical analysis in fact suggests that the composition of the dolomite is $\left(\mathrm{Ca}_{.56} \mathrm{Mg}_{.39} \mathrm{Fe}_{.05}\right) \mathrm{CO}_{3}$, although the calculated $\mathrm{Ca}$ content may be slightly high because small amounts of calcite are also commonly present in the intermediate zone. However, a $\mathrm{Ca}$ - and $\mathrm{Fe}$-rich compo- 

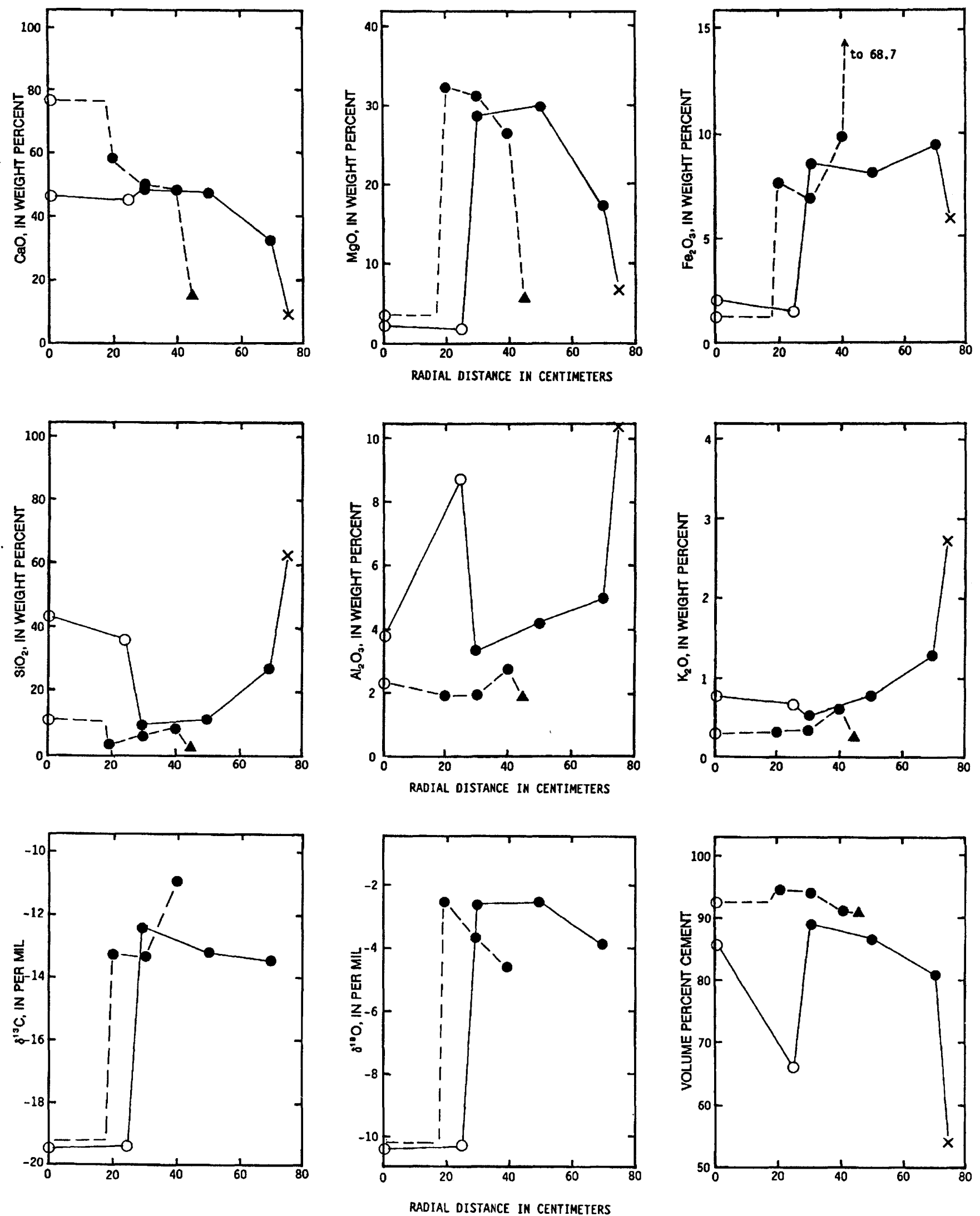
Table 1. X-Ray Spectrochemical Data For Concretions From the Huron Member of the Ohio Shale (in weight percent)

\begin{tabular}{|c|c|c|c|c|c|c|c|c|c|c|c|c|c|}
\hline Sample & Zone & & $\begin{array}{l}\text { Distance } \\
\text { on }\end{array}$ & $\mathrm{SiO}_{2}$ & $\mathrm{Al}_{2} \mathrm{O}_{3}$ & $\mathrm{Fe}_{2} \mathrm{O}_{3}$ & $\mathrm{Mgn}$ & $\mathrm{CaO}$ & $\mathrm{K}_{2} \mathrm{O}$ & $\mathrm{TiO}_{2}$ & Total & $\begin{array}{l}\text { wt. \% } \\
\text { Cement }\end{array}$ & $\begin{array}{l}\text { Vol. \% } \\
\text { Cement }\end{array}$ \\
\hline $\begin{array}{r}\text { T3A-1 } \\
2 \\
3 \\
4 \\
5 \\
6\end{array}$ & \multicolumn{2}{|c|}{$\begin{array}{l}\text { Central } \\
\text { Central } \\
\text { Intermediate } \\
\text { Intermediate } \\
\text { Intermediate } \\
\text { "Shale" }\end{array}$} & $\begin{array}{l}0 \\
25 \\
30 \\
45 \\
60 \\
65\end{array}$ & $\begin{array}{r}43.42 \\
36.14 \\
9.41 \\
11.36 \\
77.92 \\
63.57\end{array}$ & $\begin{array}{r}3.57 \\
8.81 \\
3.29 \\
4.23 \\
5.06 \\
10.50\end{array}$ & $\begin{array}{l}1.96 \\
1.55 \\
8.69 \\
8.23 \\
9.61 \\
5.84\end{array}$ & $\begin{array}{r}2.33 \\
1.86 \\
28.80 \\
29.90 \\
17.56 \\
6.57\end{array}$ & $\begin{array}{r}46.93 \\
45.32 \\
48.79 \\
47.38 \\
32.18 \\
9.30\end{array}$ & $\begin{array}{l}.81 \\
.69 \\
.55 \\
.77 \\
1.30 \\
2.74\end{array}$ & $\begin{array}{r}.19 \\
1.19 \\
.15 \\
.17 \\
.33 \\
.46\end{array}$ & $\begin{array}{r}99.21 \\
9.56 \\
99.68 \\
102.04 \\
93.96 \\
98.98\end{array}$ & $\begin{array}{l}87.9 \\
69.2 \\
91.1 \\
88.6 \\
83.2 \\
57.3\end{array}$ & $\begin{array}{l}86.3 \\
66.0 \\
89.1 \\
87.1 \\
81.1 \\
53.8\end{array}$ \\
\hline $\begin{array}{r}\mathrm{T} C-1 \\
2 \\
3 \\
4 \\
5\end{array}$ & \multicolumn{2}{|c|}{$\begin{array}{l}\text { Central } \\
\text { Intermediate } \\
\text { Intermediate } \\
\text { Intermediate } \\
\text { Pyrite }\end{array}$} & $\begin{array}{r}0 \\
20 \\
30 \\
40 \\
45\end{array}$ & $\begin{array}{l}11.52 \\
2.71 \\
6.04 \\
8.85 \\
2.24\end{array}$ & $\begin{array}{l}2.35 \\
1.97 \\
1.98 \\
2.79 \\
1.89\end{array}$ & $\begin{array}{r}1.35 \\
7.70 \\
6.88 \\
9.80 \\
68.73\end{array}$ & $\begin{array}{r}3.04 \\
32.49 \\
29.47 \\
26.52 \\
5.58\end{array}$ & $\begin{array}{l}76.72 \\
57.73 \\
50.02 \\
48.56 \\
15.03\end{array}$ & $\begin{array}{l}.34 \\
.35 \\
.36 \\
.65 \\
.26\end{array}$ & $\begin{array}{l}.24 \\
.07 \\
.09 \\
.14 \\
.11\end{array}$ & $\begin{array}{l}95.56 \\
99.02 \\
94.84 \\
97.31 \\
93.84\end{array}$ & $\begin{array}{l}93.0 \\
94.8 \\
94.5 \\
92.2 \\
93.8\end{array}$ & $\begin{array}{l}92.0 \\
94.1 \\
93.7 \\
91.1 \\
90.8\end{array}$ \\
\hline \multicolumn{2}{|c|}{$\begin{array}{l}\text { Concretion } \\
\text { (Westgate, 1926) }\end{array}$} & Int? & - & 15.88 & 3.27 & 8.80 & 24.13 & 47.72 & - & 0.21 & $(100)$. & 90.9 & 89.6 \\
\hline \multicolumn{2}{|c|}{$\begin{array}{l}\text { Uhio Shale }{ }^{\star} \\
\text { (Westgate, 1926) }\end{array}$} & Shale & - & 63.64 & 22.77 & 6.30 & 1.71 & 0.48 & 5.10 & - & $(100)$. & 0 & 0 \\
\hline
\end{tabular}

Wet chemical analyses recalculated to 100 percent for the indicated constituents.

sition (apparent $\mathrm{CaCO}_{3}$ content $=56$ to 57 mole percent) for the dolomite would be consistent with the $2.906 \AA$ spacing of the 104 peak that we have observed in several samples (see Murata and others, 1972). Of all the intermediate zone samples, only T3A-5 and Westgate's (1926) concretion have $\mathrm{SiO}_{2}: \mathrm{Al}_{2} \mathrm{O}_{3}$ ratios sufficiently large, relative to Westgate's shale, to suggest that significant authigenic quartz is present. Furthermore, the clay-related oxides, in this case including most of the $\mathrm{SiO}_{2}$, all show a clear-cut radial increase in the intermediate zone. Note that $\mathrm{TiO}_{2}: \mathrm{Al}_{2} \mathrm{O}_{3}$ is essentially constant $(\cong 0.05)$ in all but one of these samples (T3A-2). However, there is some evidence for a radial increase in $\mathrm{K}_{2} \mathrm{O}: \mathrm{Al}_{2} \mathrm{O}_{3}$, indicating either that a record of progressive diagenetic fixation of potassium by clays is preserved within the concretions or that an (assumed) initially

Figure 6. Graphs showing radial distribution of chemical contents and $\delta^{18} \mathrm{O}$ and $\delta^{13} \mathrm{C}$ values in concretions T3A (solid line) and T3C (dashed line, in part inferred) from Worthington, Ohio. Open circles represent centralzone samples, solid circles represent samples of the dolomitic intermediate zone, solid triangle represents pyrite band, and $x$ represents carbonate-cemented shale immediately peripheral to concretion. The data indicate the marked differences in the chemical and isotopic compositions of different zones in the concretions. Except for the calcite centers and the thin pyrite shell, the amount of shale incorporated in the concretions increases radially outward, while the proportion of authigenic constituents decreases. See text and tables 1 and 2 . uniform clay composition was subsequently modified by diffusional influx of potassium from a chemically evolving pore fluid.

An analysis of "shale" immediately outside one of the concretions (T3A-6) shows the expected higher concentrations of the clay-related oxides, but comparison with Westgate's (1926) shale analysis strongly suggests that authigenic dolomite, quartz, and pyrite also occur in this sample. Last, an analysis of the thin pyrite shell on one of the concretions (T3C-5) indicates that dolomite and shale constituents are present, in addition to pyrite.

An important feature of our analyses is that they permit approximate computation of the relative proportions of authigenic constituents and incorporated shale material in radial traverses through the concretions. Although there is no completely satisfactory way to make such computations, particularly from our partial chemical analyses, we propose that it is reasonable to (1) assume that the oxide ratios of shale constituents in the concretions are exactly the same as those in Westgate's (1926) complete analysis of the shale; (2) determine the quantity of incorporated shale in the concretion samples from the $\mathrm{Al}_{2} \mathrm{O}_{3}$ contents and the above assumption; and (3) recalculate any unaccounted $\mathrm{CaO}, \mathrm{MgO}, \mathrm{Fe}_{2} \mathrm{O}_{3}$ and $\mathrm{SiO}_{2}$ as authigenic carbonates and quartz. Note that computation of all authigenic iron as carbonate is acceptable for our purpose because siderite has nearly the same formula weight as pyrite.

The results of the calculations are given in table 1 . The proportion of the authigenic constituents in most concretion samples ranges from 83 to 95 weight percent, 
and would translate to approximately 81 to 94 volume percent, given reasonable assumptions of the mineral densities. Furthermore, there appears to be a progressive radial decrease in authigenic constituents, particularly if the central zone samples are excluded. This result accords with the observations of Lippmann (1955), Raiswell (1971), and Oertel and Curtis (1972), who interpreted similar data in terms of concretion growth by cementation of pore space during progressive compaction of the host shale. The relatively low cement contents of the calcite centers might indicate late-stage dissolution of calcite. Such dissolution might ultimately have been responsible for the septarian cracks and the peculiar "funnel-shaped" depressions at the top and bottom of some concretions. Last, in partial support of our calculations we point out that Westgate (1926) recalculated his complete chemical analysis in terms of 85.2 weight percent carbonate, and this, along with the small amount of authigenic quartz and pyrite in the sample, would approximately equal the value of 91 weight percent that we calculated by our method for all authigenic components (table 1).

\section{Carbon and Oxygen Isotope Data}

$\delta^{13} \mathrm{C}$ and $\delta^{18} \mathrm{O}$ analyses were made of several large and small concretions from the Huron Member of the Ohio Shale at Worthington, Ohio (table 2). The $\delta^{13} \mathrm{C}$ $(-19.9 \pm 0.5)$ and $\delta^{18} \mathrm{O}(-10.2 \pm 0.2)$ values of calcite from the centers of the large concretions are strikingly uniform. The "late calcites" that fill cracks and vugs in the concretions typically have similar values, as does one sample of a 3-cm-thick, cone-in-cone layer in the shale (table 2).

Isotopic analyses of dolomite from the intermediate zone of the large concretions $\left(-11.0 \leq \delta^{13} \mathrm{C}\right.$ $\left.\leq-13.3 ;-4.6 \leq \delta^{18} \mathrm{O} \leq-2.5\right)$ are significantly different from those of the calcites. A distinct radial decrease of $\delta^{18} \mathrm{O}$ in the dolomitic matrix is evident in the large concretions (T3A and T3C) and in some of the small concretions. The $\delta$-values of the dolomite in the small concretions are similar to those of the outermost parts of the large concretions (T3C-4), although it is notable that the largest of these small concretions (T2S; $0.25-\mathrm{m}$ diam) is isotopically similar to dolomite well inside the large concretions (T3A-3,4). Dolomite from a small, pyriterimmed concretion from Milan, Ohio $\left(\delta^{13} \mathrm{C}=-10.1\right.$, $\left.\delta^{18} \mathrm{O}=-5.4\right)$ is isotopically very similar to the small concretions from Worthington. Taken together, the $\delta^{13} \mathrm{C}$ and $\delta^{18} \mathrm{O}$ values of all the concretionary dolomites form a common trend line (fig. 7).

In cases where analyses were made of different $\mathrm{CO}_{2}$ fractions from a single sample, both the $\delta^{13} \mathrm{C}$ and $\delta^{18} \mathrm{O}$ values of the minor fractions (in brackets, table 2)
Table 2. Isotopic composition of concretions from the Huron Member of the Ohio Shale, Worthington, Ohio

\begin{tabular}{|c|c|c|c|c|}
\hline $\begin{array}{l}\text { Nodile } \\
\text { No. }\end{array}$ & $\begin{array}{c}\text { Sarple } \\
\text { Na. }\end{array}$ & $\begin{array}{l}\text { Mineralogy (1) } \\
\text { I. LARCE MMULES }\end{array}$ & 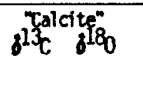 & glolomite" \\
\hline T3A & $\begin{array}{l}1 \text { Central zone } \\
2 \text { Central zone } \\
3 \text { Intemediate zone } \\
4 \text { Intermedlate zone } \\
5 \text { Intemediate zone }\end{array}$ & 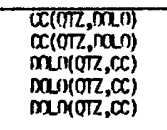 & $\begin{array}{ll}-19.5 & -10.4 \\
-19.4 & -10.3 \\
(-11.2 & -3.6) \\
(-12.2 & -4.1)\end{array}$ & $\begin{array}{rr}(-18.0 & -9.3, \\
-12.5 & -2.6 \\
-13.2 & -2.5 \\
-13.5 & -3.9\end{array}$ \\
\hline$\sqrt{3 C^{*}}$ & $\begin{array}{l}\text { 2. Intermediate zone } \\
3 \text { Internediate zone } \\
4 \text { Intemedfate zone }\end{array}$ & $\begin{array}{l}\text { DOL1 } \\
\text { Dow } \\
\text { now }\end{array}$ & $\begin{array}{l}(-12.6=3.2) \\
(-13.4=3.3) \\
(-11.4=4.8)\end{array}$ & $\begin{array}{ll}-13,3 & -2.5 \\
-13.4 & -3.7 \\
-11.6 & -4.6\end{array}$ \\
\hline 15 & $\begin{array}{l}1 \text { Central zone, with } \\
\text { fossil wood mucleus } \\
2 \text { lntermediate zone }\end{array}$ & $\begin{array}{l}\text { (x)(OTZ) } \\
\text { Dan }\end{array}$ & $-20.0-10.1$ & $-12.1-4.1$ \\
\hline TरR & $\begin{array}{l}\text { I Central zone, with } \\
\text { arthrodire plate nucleas } \\
2 \text { Intermediate zone }\end{array}$ & $\begin{array}{l}\text { CETOKL) } \\
\text { nao }\end{array}$ & $-20.4-10.2$ & $-12.8-3.3$ \\
\hline & & 11. SMLL NUDRES & & \\
\hline हि & $\begin{array}{l}1 \text { Inner intemediate zone } \\
2 \text { arter intermediate zone }\end{array}$ & $\begin{array}{l}\text { mo } \\
\text { Dowo }\end{array}$ & $(-7.7-5.4)$ & $\begin{array}{ll}-9.3 & -5.3 \\
-9.2 & -5.3\end{array}$ \\
\hline$\overline{2}$ & $\begin{array}{l}1 \text { Inner intenmediate zone } \\
2 \text { Outer intermedlate zone }\end{array}$ & $\begin{array}{l}\text { Don } \\
\text { Don }\end{array}$ & 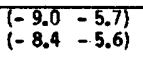 & $\begin{array}{ll}-9.3 & -5.1 \\
-9.2 & -5.5\end{array}$ \\
\hline T2 & $\begin{array}{l}1 \text { Imer intermediate zone } \\
2 \text { outer intermedi ate zone }\end{array}$ & $\begin{array}{l}\text { mul } \\
\text { mol }\end{array}$ & 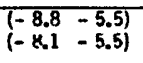 & $\begin{array}{ll}-9.4 & -5.3 \\
-9.3 & -5.1\end{array}$ \\
\hline \multirow[t]{2}{*}{ TES } & $\begin{array}{l}1 \text { Inner intemediate zone } \\
2 \text { ater intenrediate zone }\end{array}$ & 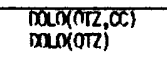 & $\begin{array}{l}(-12.4-0.9) \\
(-12.9-3.9)\end{array}$ & $\begin{array}{ll}-12.6 & -2.8 \\
-12.6 & -3.0\end{array}$ \\
\hline & & 1. " "ATE" CALCITE & & \\
\hline T35Y & $\begin{array}{l}\text { I hug in large nodule } \\
2 \\
3 \\
4 \\
6\end{array}$ & $\begin{array}{l}\propto(0) 2) \\
\alpha \\
\propto \\
\propto \\
\propto\end{array}$ & $\begin{array}{ll}-20.2 & -10.3 \\
-15.2 & -10.5 \\
-23.0 & -10.7 \\
-17.3 & -10.4 \\
-20.3 & -10.7\end{array}$ & \\
\hline TिY & $\begin{array}{l}1 \text { Crack filling in } \\
\text { large nodule }\end{array}$ & 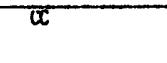 & $-16.7-9.8$ & \\
\hline$T 3 x$ & 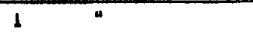 & $\alpha$ & $-18.6-9.9$ & \\
\hline$T$ & $T$ & $\ddot{c}$ & $-23.3-10.9$ & \\
\hline T3N & T & $\operatorname{TC}(0,2)$ & $-18.9-9.6$ & \\
\hline CIC & ICone-in-cone Thestone & CC(OTZ) & $-21.5-9.7$ & \\
\hline
\end{tabular}

(1) Determined by $x$-ray diffraction; $\propto=$ calcite; $00.0=$ dolowite; Orz = qartz. (ii) Samle T3C-1 was lost.

tend to mirror those of the principal phase and may reflect significant contamination. Thus, no systematic differences between the $\delta^{13} \mathrm{C}$ values of coexisting concretionary calcite and dolomite are observed. However, in all but one instance the dolomite has a slightly higher $\delta^{18} \mathrm{O}$ value than the coexisting calcite. Because this minor ${ }^{18} \mathrm{O}$ enrichment in the dolomite $\mathrm{CO}_{2}$ could primarily reflect the different acid extraction fractionations of the two carbonate phases (Sharma and Clayton, 1965), primary ${ }^{18} \mathrm{O}$ fractionation between the phases is not necessarily indicated by the data.

Four analyses $\left(\delta^{18} \mathrm{O}=+23.4\right.$ to $+25.3 \mathrm{rel}$. SMOW $)$ were made of quartz crystals that line vugs in large concretions from Worthington, Ohio (table 3). Analyses of calcite in two of these vugs are highly distinct (approx. $\delta^{13} \mathrm{C}=+16 ; \delta^{18} \mathrm{O}=-5$ ) from those of the other vug and vein calcites we have measured (table 2). Analyses were also made of calcite from the center $\left(\delta^{13} \mathrm{C}=-11.4\right.$; 


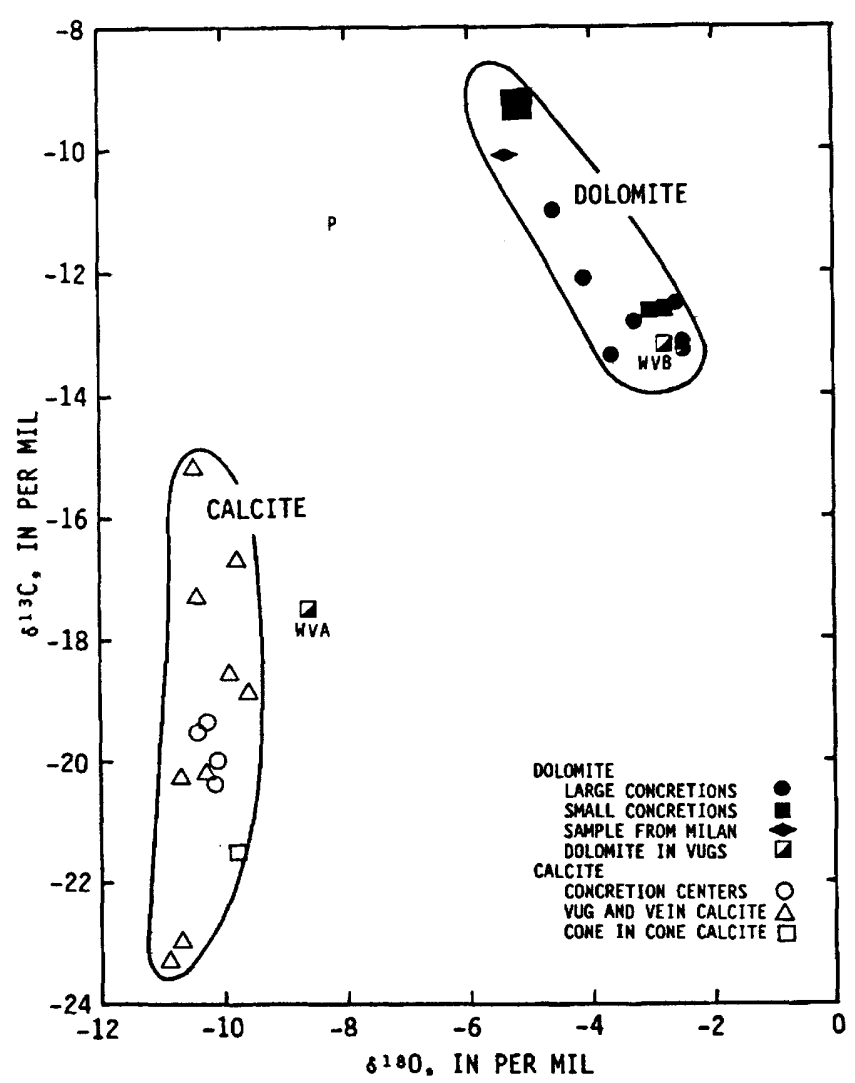

Figure 7. Graph of $\delta^{18} \mathrm{O}$ vs. $\delta^{13} \mathrm{C}$ values of carbonate concretions from the Huron Member of the Ohio Shale. Note that the $\delta^{13} \mathrm{C}$ values are generally low and indicate an organic source for the carbon. The $\delta^{18} \mathrm{O}$ values of the dolomitic matrix of the large concretions are a few per mil lower than values typical of unaltered marine limestones, and indicate concretion formation at low to moderate temperatures. Dolomite samples from small concretions, including the sample from Milan, as well as dolomite crystals from vug WVB, lie on a trend line that includes samples of the dolomitic matrix of the large concretions. $\delta^{18} \mathrm{O}$ values of calcite from concretion centers, vugs, veins, and a cone-in-cone layer in the shale are isotopically uniform, indicating that late-stage recrystallization and isotopic reequilibration occurred at elevated temperatures in the presence of infiltrating formation water. This event may have been similar to that which produced calcite in vugs in dolostone at Pugh Quarry (sample P); however, the $\delta^{13} \mathrm{C}$ values of the concretionary carbonates are significantly lower than sample $P$, probably reflecting exchange of the late-stage fluid with the abundant, ${ }^{13} \mathrm{C}$ depleted organic matter in the shale. Vug calcites WVC $\left(\delta^{18} \mathrm{O}=-4.8\right.$; $\left.\delta^{13} \mathrm{C}=+15.9\right)$ and WVD $\left(\delta^{18} \mathrm{O}=-5.2 ; \delta^{13} \mathrm{C}=+16.4\right)$ are offscale, and probably formed at a very late stage. Data from tables 2 and 3.

$\left.\delta^{18} \mathrm{O}=-5.6\right)$ and outer part $\left(\delta^{13} \mathrm{C}=-1.3 ; \delta^{18} \mathrm{O}=-6.0\right)$ of 1-m-diameter calcite concretion from the Kettle Point Shale, Kettle Point, Ontario. Last, calcite from a vug in Devonian dolostone at Pugh Quarry, Ohio, had $\delta^{13} \mathrm{C}=-11.2$ and $\delta^{18} \mathrm{O}=-8.2$.

Published $\delta^{13} \mathrm{C}$ values of organic matter in the Huron Member of central Ohio are quite low $(\cong-30 \pm 0.2)$, and indicate the presence of both marinederived and terrestrially derived organic matter (Maynard, 1981). The $\delta^{13} \mathrm{C}$ value of Foerstia collected a few meters above the uppermost carbonate concretion horizons at Worthington was -25.4, typical of values of Devonian terrestrial organic matter (Romankiw and others, in press).

The $\delta^{13} \mathrm{C}$ and $\delta^{18} \mathrm{O}$ values of the Huron Member concretions are similar to those of diagenetic carbonate concretions from many other marine sequences (Hodgson, 1966; Tourtelot and Rye, 1969; Hudson and Friedman, 1976). Such concretions almost invariably have low $\delta^{13} \mathrm{C}$ values that are much closer to those of marine organic matter than to those of normal marine limestones, yet they typically have $\delta^{18} \mathrm{O}$ values that are either similar to, or a few per mil lower than, those of normal marine limestones, as demonstrated by Hodgson (1966). Interpretations of the $\delta^{13} \mathrm{C}$ and $\delta^{18} \mathrm{O}$ data from the Huron Member concretions are discussed below in turn.

\section{Interpretation of the $\delta^{13} \mathrm{C}$ Values}

A variety of mechanisms has been proposed whereby the carbon in organic materials may become incorporated in diagenetic carbonates (Cheney and Jensen, 1965; Hodgson, 1966; Hathaway and Degens, 1969; Berner, 1968; Irwin and others, 1977). None of these mechanisms can be completely ruled out as contributory to growth of the concretions in the Huron Member of the Ohio Shale, because most are consistent with the low $\delta^{13} \mathrm{C}$ values. Simultaneous operation of more than one process could have occurred. However, when taken together, several characteristics of the Huron Member concretions point to Berner's (1968) suggestion that rapidly grown, low $\delta^{13} \mathrm{C}$ calcium carbonate concretions may have originated as bodies of adipocere (organic soap; $\left.\mathrm{Ca}(\mathrm{RCOO})_{2}\right)$.

Several investigators have described adipocere concretions that have formed about decaying proteinaceous organisms on short time scales (Bergmann, 1963; Sondheimer and others, 1966). Berner (1968) produced this material in laboratory experiments of anaerobic decomposition of fish in seawater, although Jackson $(1973$, p. 31) pointed out that organic gels can form when samples that have not been treated to remove calcium

Table 3. $\delta^{18} \mathrm{O}$ Determinations of coexisting vug minerals in concretions of the Huron Member

\begin{tabular}{|c|c|c|c|c|}
\hline SAMPLE & $0^{18} 0$ Quartz, smow & giln SAN (PDB) Carbonate & $8^{13}$, Cartonate & Relation \\
\hline WNA & +23.4 & $+\$ 2.0(-8.6)$ no.0 & -17.5 Da. & nol. on QR \\
\hline WB & +25.3 & $+28.0(-2.8) D 00$ & -13.2 mo & QRz on DOL \\
\hline we & +25.1 & $+\infty .9(-4.8) \propto C$ & $+15.9 \propto C$ & $x$ on QTा. \\
\hline w & +24.4 & $+25.5(-5.2) \propto$ & $+16.4 \propto$ & $?$ \\
\hline
\end{tabular}


Table 4. Concretions from other localities - This study and others

\begin{tabular}{|c|c|c|c|c|}
\hline Sample No. & nescription & Mineralogy $(1)$ & $8^{13}+(x)$ & $8^{18} n(x)$ \\
\hline$M S-1$ & $\begin{array}{l}\text { Ellipsoidal, fish-hearing } \\
\text { concret ion. Lower Creta- } \\
\text { ceaus marine seriments, } \\
\text { fahia Series, fahta, } \\
\text { Brazil. }\end{array}$ & $\begin{array}{l}\text { caleite } \\
\text { (quartz?) }\end{array}$ & -13.8 & -3.8 \\
\hline 10934 & $\begin{array}{l}\text { Elipsoidal concretion } \\
\text { containing the fish } \\
\text { Tharrtis sp. Cretaceous } \\
\text { marine (?) sediments. } \\
\text { Sartant } \mathrm{Fm}_{*} \text {, Ceara, } \\
\text { Brazil. }\end{array}$ & calcite & -9.8 & -6.3 \\
\hline $\begin{array}{l}\text { 66-229 } \\
\text { (Keith and } \\
\text { Weber, 1964) }\end{array}$ & $\begin{array}{l}\text { "Limestone", fish-bearing } \\
\text { concretion. Marine Creta" } \\
\text { ceous. Grizzly Bear } \\
\text { Muns., Grt. Bear Lake, } \\
\text { N.N.T., Canada. }\end{array}$ & - & -15.8 & -4.5 \\
\hline 8014 & $\begin{array}{l}\text { Small, ellipsoldal, fish } \\
\text { (Mallotus?) bearing con- } \\
\text { cretion. Pleistocene } \\
\text { glacial clay (marine), } \\
\text { Leda Clay Fm, carlton, } \\
\text { co., Ontario, Canada. }\end{array}$ & $\begin{array}{l}\text { caicite with } \\
\text { ca. } 9 \text { wt. }^{2} \\
\operatorname{mon}_{3} \text { in solid } \\
\text { soln. (quartz, } \\
\text { feldspor) }\end{array}$ & -18.1 & -6.2 \\
\hline 8212 & $\begin{array}{l}\text { El lipsoidal concretion } \\
\text { containing hone of } \\
\text { Dnkleosteus. Upper } \\
\text { Devonian Cleveland Perber, } \\
\text { Clevelam, Ohio. }\end{array}$ & $\begin{array}{l}\text { dolomite, } \\
\text { quartz }\end{array}$ & -22.5 & -4.5 \\
\hline $\begin{array}{l}\text { F1f5 } \\
\text { (Sass and } \\
\text { Kolochy, 1972) }\end{array}$ & $\begin{array}{l}\text { "Lfmestone" concretion } \\
\text { with fish skeleton. } \\
\text { (lpper Cretaceous } \\
\text { mishash tim, (marine). } \\
\text { Isreel. }\end{array}$ & -- & $\begin{array}{l}-9.5 \text { to } \\
-13.8\end{array}$ & $\begin{array}{l}-1.5 \text { to } \\
-3.0\end{array}$ \\
\hline 8325 & $\begin{array}{l}\text { Dolomite concretion } \\
\text { containing Cladosalache sp. } \\
\text { with well-preserved trunk } \\
\text { misculature, Devonian } \\
\text { Clevel and Shale, Cleveland, } \\
\text { Ohio. }\end{array}$ & $\begin{array}{l}\text { dolorite, } \\
\text { quartz }\end{array}$ & -22.8 & -0.9 \\
\hline
\end{tabular}

1)etemined by x-ray diffraction.

$2 d(10)=3.010 \mathrm{~A}$, composition determined by the method of Chave (1\%2).

Descriptions of these samples and formations may be found in Meeks (1957), Grimaraes (1964), Romer (1971), Keith and Heher (1964), Dawson (1894), Hover (1960), Sass and Kolochy (1972), and Dean (1912).

Samples 15-1, 10534, 8014, and $\$ 272$ and 8325 were provided by the Cleveland Museam of Natural History. To avoid damage to fossils within specimers $16-1,10934$, and 8014 , samples were tiken near the exterior of the concretiors.

are treated with $\mathrm{H}_{2} \mathrm{O}_{2}$. Berner (1968) pointed out that the decomposition of adipocere to calcium carbonate would necessitate considerable shrinkage of the concretions because of the large density difference between the two materials.

The observational and inferential features of the Huron Member concretions that are consistent with Berner's (1968) hypothesis include (1) concretionary nuclei of arthrodire fish; (2) evidence for rapid growth of the concretions near the sediment-water interface; (3) evidence for shrinkage and recrystallization of the concretions; (4) evidence for low-oxygen fugacity in the black shale; and (5) low $\delta^{13} \mathrm{C}$ values of the carbonate. Furthermore, a paradox that is associated with the second of the above features may be uniquely indicative of a lowdensity precursor for the concretions; notably, the density of the extremely porous ( $\Phi>80$ percent) sediment near the sediment-water interface would have been much too low $(\rho<1.5)$ to hydrostatically support the large, rapidly grown carbonate concretions that now have $\rho \cong 3 \mathrm{~g} / \mathrm{cc}$.

As a partial test of Berner's (1968) hypothesis, we analyzed fish-bearing concretions from several other localities and present the isotopic data in table 4 along with pertinent determinations made by Keith and Weber
(1964) and Sass and Kolodny (1972). Rapid concretionary growth is suggested by the excellent preservation of fish within samples MS-1, 10934, 8014, 8272, and 8325 (fig. 8). Of particular note are sample 10934, which resembles the extraordinary concretions described by Weeks (1957) in that the original, three-dimensional external shape of the fish is preserved; and sample 8325, in which the external form and trunk musculature of a cladodont shark are preserved (fig. $8 A, B$; also see Dean, 1902). The $\delta^{13} \mathrm{C}$ values of these samples are generally similar to one another and to those of the Huron Member concretions. Because an adipocere origin is probably quite likely for at least some of these concretions, and because all our samples have numerous petrographic and isotopic similarities, the available evidence is compatible with an adipocere origin for all fish-bearing concretions examined thus far.

Although we think that the circumstantial evidence pointing to an adipocere origin for the Huron Member concretions is very strong, some of our observations seem to be incompatible with this model. First, most of the shrinkage and cracking of the Huron Member concretions is confined to the calcite inner zone, and therefore probably occurred after the dolomite replacement stage, which should significantly postdate the conversion of adipocere to calcite. Furthermore, no indications of significant shrinkage were observed in any of the fishbearing concretions described in table 4 . Second, several investigators report that bone material associated with adipocere tends to dissolve or decalcify (Weigelt, 1935; Sondheimer and others, 1966), but no definite evidence for this has been found in the Huron Member concretions. We cannot fully account for these discrepant observations, although it is noteworthy that reports of bone decalcification are confined to freshwater environments and might not apply to marine environments because abundant calcium is available in the pore fluids. Last, our analyses clearly show that the isotopic compositions of the Huron Member concretions do not seem to depend on the type of fossil nucleus present (cf. T3R and T3F, table 2). However, Sondheimer and others (1966) proved that most of the adipocere in the concretions he described was derived from sources external to the nuclei, and this might account for the latter observations.

\section{Interpretation of the $\delta^{18} \mathrm{O}$ Values}

In general, the $\delta^{18} \mathrm{O}$ values of carbonate minerals reflect the temperature and isotopic composition of the fluid from which they precipitated (Epstein and others, 1953). The sequentially grown carbonate minerals in concretions may therefore preserve a temporal record of diagenetic changes in pore fluid characteristics, as suggested by Hudson and Friedman (1976). The isotopic record of the concretions in the Huron Member of the 

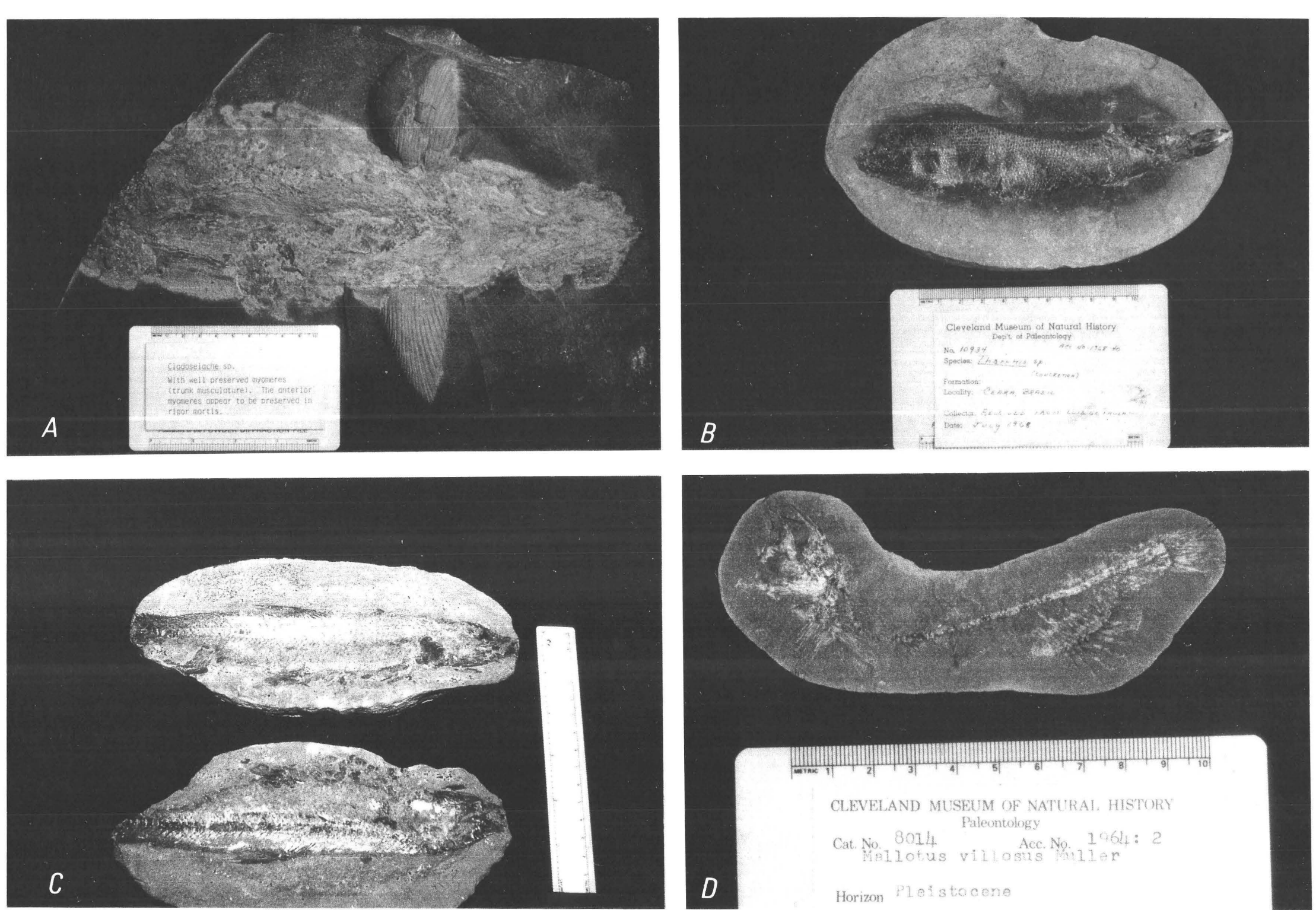

Figure 8. Photographs of carbonate concretions with fossil fish from several localities. All samples are curated by the Cleveland Museum of Natural History. Scale bar is $10 \mathrm{~cm}$ long on $A, B$, and $D$ and $15 \mathrm{~cm}$ long on $C$. See table 4 for isotopic analyses and additional information. A. Ellipsoidal dolomitic concretion from the Cleveland Member, Cleveland, Ohio, containing shark (Cladoselache sp.) with well-preserved trunk musculature (sample 8325). B. Ellipsoidal calcite concretion containing fish (Tharrhis sp.) with external, three-dimensional shape preserved, Ceara, Brazil (sample 10934). C. Ellipsoidal, fish-bearing calcite concretion, Bahia, Brazil (sample MS-1). D. Ellipsoidal to irregular, fish-bearing calcite concretion, Ontario, Canada (sample 8014). 
Ohio Shale has been greatly modified by recrystallization and replacement and cannot be interpreted independently of field and petrographic data, but most of our samples record an overall pattern of progressive ${ }^{18} \mathrm{O}$ depletion in the concretionary carbonates. Such a temporal pattern has been found in concretions from several other localities (Sass and Kolodny, 1972; Coleman and Raiswell, 1981) and probably represents the major and most common trend, although complex patterns (Hennessy and Knauth, 1985; Siegel and others, 1987) and even reversed trends (Degens and others, 1962) can occur.

The isotopic similarity of almost all of the "late calcites" and of the calcite centers of the concretions, together with the coarse grain size of the latter, strongly suggest that recrystallization and complete isotopic reequilibration of the calcite centers occurred at a late stage. The original isotopic character of the concretions is therefore probably best preserved in the dolomite of the intermediate zone, but this dolomite grew by replace. ment of preexisting calcite, and this process will closely (Degens and Epstein, 1964), but in general not perfectly (Land, 1980), replicate the $\delta^{18} \mathrm{O}$ value of the precursor, depending on the water/rock ratio during replacement. Furthermore, isotopic fractionations attendant on the conversion of adipocere to calcite are not known, and such a process may have occurred in the Huron Member concretions, as previously discussed. In spite of these complexities, it is probably not accidental that the $\delta^{18} \mathrm{O}$ values of the matrix dolomites are either close to, or only a few per mil lower than, the values observed in Quaternary marine limestones (Keith and Weber, 1964), and that these dolomites appear to preserve a progressive (radial) record of $\delta^{18} \mathrm{O}$ depletion (see table 2). The $\delta^{18} \mathrm{O}$ values of the dolomite zone are accordingly compatible with crystallization at low but progressively higher temperatures in the presence of a pore fluid with a $\delta^{18} \mathrm{O}$ value similar to that of seawater.

Similarly, the $\delta^{18} \mathrm{O}$ values of the carbonates $(-0.9$ to -6.3) of fish-bearing concretions from other localities also suggest precipitation at low temperatures from fluids with $\delta^{18} \mathrm{O}$ values similar to, or somewhat lower than, seawater (table 4). It is significant that the lowest values in table 4 represent the carbonate from the outermost part of the concretions and probably reflect growth at a late stage when temperatures were elevated and pore fluid $\delta^{18} \mathrm{O}$ values may have been somewhat lower than the seawater value.

The geologic history of the "late calcites" and other vug minerals in the Huron Shale concretions would seemingly be straightforward compared to that of the matrix carbonates. The relatively low $\delta^{18} \mathrm{O}$ values $(\cong-10)$ of most of these "late calcites" are compatible with either (1) formation in seawater-like fluid at elevated temperatures $\left(\cong 75^{\circ} \mathrm{C}\right)$; $(2)$ formation at low tempe- ratures in fluid with a $\delta^{18} \mathrm{O}$ value approximately 10 per mil lower than that of seawater, for example, from meteoric waters (although -7 would probably be a better average value for modern meteoric waters in Ohio); or (3) formation under many other combinations of temperature and fluid $\delta^{18} \mathrm{O}$ values, with the restriction that only one variable is independent.

In an attempt to resolve this history, we made $\delta^{18} \mathrm{O}$ analyses of quartz crystals coexisting with either calcite or dolomite from four vugs in the large concretions (table $3)$. Although the $\delta^{18} \mathrm{O}$ values of the quartz samples are quite uniform (+23.4 to +25.3 rel. SMOW), in three of the four cases the carbonates have higher $\delta^{18} \mathrm{O}$ values than the quartz; the marked isotopic disequilibrium in these three vugs indicates that the minerals did not coprecipitate. Only quartz and dolomite from vug WVA can possibly be in oxygen isotope equilibrium; unfortunately, the temperature dependence of the isotopic fractionation between quartz and dolomite has not yet been well determined. If it is assumed that the ${ }^{18} \mathrm{O}$ fractionation between dolomite and calcite at low to moderate temperatures is 3 to 4.5 per mil (see Land, 1980; also see fractionations compiled in Friedman and O'Neil, 1977), then the data from WVA translate to temperatures of 45 ${ }^{\circ} \mathrm{C}$ to $95{ }^{\circ} \mathrm{C}$ and a fluid $\delta^{18} \mathrm{O}$ value of -7.2 to +1.2 , utilizing the quartz-water fractionation curve of Clayton and others (1972) with the calcite-water fractionation curve of O'Neil and others (1969). Note that the dolomite in WVA has an isotopic composition that is generally compatible with that of most of the observed vug and vein calcites (table 2; fig. 7). In contrast, the dolomite in vug WVB is isotopically similar to that of the dolomitic matrix of the concretions (see fig. 7), but is quite different from that of the other vug and vein carbonates, and probably precipitated much earlier than the quartz and the other vug and vein minerals.

An additional surprise is that the $\delta^{18} \mathrm{O}$ and $\delta^{13} \mathrm{C}$ values of the calcites in vugs WVC and WVD are both dramatically different from the values observed in all the other vug and vein calcites (table 2). It is unfortunate that temporal relations between these unusual calcites and the other vug minerals could not be completely determined, although calcite appears to postdate quartz in vug WVC. Also, the observations of Siegel and others (1987) strongly suggest that their calcite IV, which is isotopically similar to calcites WVC and WVD at Worthington, formed during a late stage of diagenesis subsequent to the precipitation of the main masses of vug carbonates. Thus, our paragenetic and isotopic evidence, and especially that of Siegel and others (1987), indicate that the $\delta^{18} \mathrm{O}$ record of sequentially precipitated vug minerals in concretions is complicated in detail, and is not entirely consistent with a simple pattern of progressive depletion of ${ }^{18} \mathrm{O}$. Note that relatively high $\delta^{18} \mathrm{O}$ values could occur in very late stage vug minerals that precipitated under 
conditions of elevated temperatures and low water/rock ratios, provided that the $\delta{ }^{18} \mathrm{O}$ value of the fluid was substantially increased by interaction with the rock, for example with the fine grained, high ${ }^{18} \mathrm{O}$ matrix carbonates. Irwin and others (1977) suggest that bacterial fermentation reactions can form carbonates with unusually high $\delta^{13} \mathrm{C}$ values.

Although our attempt to definitively resolve the origin of the late-stage minerals met with some difficulty, we believe that the most likely possibility is a case only marginally different from (1), above. For example, if it is assumed that the vug quartz and the ordinary (ca. -10 ; table 2) late calcites formed simultaneously, which is probably not rigorously true because these minerals tend to precipitate under different acid-base conditions, both the temperature and the $\delta^{18} \mathrm{O}$ value of the fluid can be calculated from the average $\delta^{18} \mathrm{O}$ values of these minerals. Thus, using available fractionation factors ( $\mathrm{O}^{\prime} \mathrm{Neil}$ and others, 1969; Clayton and others, 1972) and the average $\delta^{18} \mathrm{O}$ values, we calculate that crystallization of these minerals occurred at $\mathrm{T} \cong 105^{\circ} \mathrm{C}$ in a pore fluid with $\delta^{18} \mathrm{O}=+3.6$. Alternatively, the largest observed ${ }^{18} \mathrm{O}$ difference between any of these quartz and calcite samples would suggest a temperature of $55^{\circ} \mathrm{C}$ and a fluid $\delta^{18} \mathrm{O}$ value of -3.5 , whereas the smallest quartz-calcite ${ }^{18} \mathrm{O}$ difference would indicate an unreasonably high temperature of $225^{\circ} \mathrm{C}$ and a fluid $\delta^{18} \mathrm{O}$ value of +12.8 .

Because the quartz, dolomite, and calcite samples utilized in the above calculations cannot be proved to have coprecipitated, we cannot claim to have definitively calculated the conditions under which crystallization of the vug minerals occurred. However, we believe that our calculated conditions for the precipitation of these "ordinary" late-stage minerals are mostly quite reasonable, in part because generally similar conditions have been commonly inferred for the development of late-stage carbonate cements in limestones (Choquette and James, 1987). Also note that fluid inclusion measurements indicate elevated temperatures $\left(50^{\circ} \mathrm{C}\right)$ for late-stage calcite crystallization in septarian concretions from the Fayetteville Formation, Arkansas; later stage fluids were as hot as $100{ }^{\circ} \mathrm{C}$ (Burruss and Goldstein, 1980; see Zangerl and others, 1969, for description of concretions from this formation). The calculated $\delta^{18} \mathrm{O}$ value of the fluid in the latter case strongly suggests that it was either slightly modified marine pore fluid or formation waters. Marine pore fluids within $1 \mathrm{~km}$ of the sediment-water interface almost invariably have $\delta^{18} \mathrm{O}$ values only slightly less (by a few per mil) than seawater (Lawrence and Gieskes, 1981). On the other hand, it is probably highly significant that present-day formation waters from the Gulf Coast and from the Illinois and Michigan basins generally have $\delta^{18} \mathrm{O}$ values of about -3 to +6 if temperatures are moderate, as our calculations suggest (see Clayton and others, 1966).
In summary, we believe that the rather low $\delta^{18} \mathrm{O}$ values of the vug minerals in the concretions of the Huron Member of the Ohio Shale reflect their precipitation at moderate temperatures from marine pore fluids or formation waters. A formation water origin is supported by the rather low $\delta^{18} \mathrm{O}$ and $\delta^{13} \mathrm{C}$ values that we observed in vug calcite at Pugh Quarry, Ohio. Also, the $\delta^{18} \mathrm{O}$ and $\delta^{13} \mathrm{C}$ values observed by Hall and Friedman (1969) in the late-stage calcites from Mississippi Valley type ore deposits are quite similar to those of Pugh quarry calcite; Hall and Friedman suggested that these calcites precipitated from hot oil-field brine mixed with meteoric water (their calculated fluid had $\delta^{18} \mathrm{O}=-3.0$ to $+0.4)$. Under the low water/rock conditions at the latest stages of diagenesis, vug calcites with high $\delta^{13} \mathrm{C}$ values and with $\delta^{18} \mathrm{O}$ values approaching those of the finegrained matrix carbonates could be formed. We do not concur with suggestions (Hudson and Friedman, 1976; Hudson, 1978) that similarly low $\delta^{18} \mathrm{O}$ values of "late calcites" in concretions from many other localities principally reflect growth in low ${ }^{18} \mathrm{O}$ pore fluids derived from meteoric waters.

\section{DISCUSSION AND CONCLUSIONS}

The carbonate concretions of the Huron Member of the Ohio Shale are structurally and petrographically complex bodies that commonly contain well-preserved fish remains. We concur with the opinions of Newberry (1873) and Clifton (1957) that the concretions originated by rapid, early diagenetic growth near the sedimentwater interface. Presuming that the concretionary material filled and preserved void space in the sediment, chemical analyses can be used to calculate that the sediment originally had a porosity of approximately 81 to 94 volume percent. Similarly large porosities are typical of modern marine sediments in the uppermost few meters of the sediment column. Such values have also been calculated for early diagenetic concretions from numerous other localities (Lippmann, 1955), but the indicated sediment densities are extremely low and pose a problem for hydrostatic support of the large, dense concretions. It must be concluded that either (1) such porosity calculations are unrealistic, perhaps because much of the original sediment contained carbonate or silica that dissolved, or perhaps because the crystals of the growing concretion have mechanically displaced much of the sediment; or (2) the concretions originated as some type of low-density material. However, even if the porosity calculations are in error by a factor of two, the paradox of hydrostatic support of the concretions would remain. Also, only the second possibility can easily account for the severe deformation observed in the concretions that were incorporated in the clastic dikes at 
Milan, Ohio. Observations at Milan also prove that joints and clastic dikes formed in the shale at a surprisingly early stage, before compaction and carbonate precipitation were complete.

The concretions have a closer spatial correspondence with the Foerstia biostratigraphic zone than they have with the diachronous base of the Huron Member. The concretionary horizons may therefore represent timelines in the formation.

Complex recrystallization and replacement phenomena have affected the carbonate concretions of the Huron Member. The concretions appear to have been, at an early stage, composed principally of calcite, which, except for remnant cores in the largest bodies, was subsequently replaced by $\mathrm{Ca}$ - and $\mathrm{Fe}$-rich dolomite. Euhedral crystals and dendrites of barite probably formed during or before this stage. The replacement stage was accompanied by the growth of small pyrite concretions in the shale and the development of pyrite rims on some of the large concretions. Subsequently the cone-in-cone layers in the shale formed. Concurrently or subsequently the remnant calcite cores recrystallized and formed the "funnel-shaped" depressions in the top and bottom of the concretions. During the late stages of development, crystals of calcite and, less commonly, quartz and dolomite, filled vugs and veins in the concretions.

$\delta^{13} \mathrm{C}$ values indicate that the source of the carbon in carbonate in the Huron Member concretions, like that of early diagenetic carbonate concretions worldwide (Hodgson, 1966), was dominantly derived from organic matter. The values are similar to those of fish-bearing concretions from many other marine sequences, and these concretions might in many cases have originated as bodies of adipocere. An adipocere origin is compatible with the rapid early diagenetic growth of the concretions and would explain the unique paradoxes related to the low density and deformable nature inferred for the concretions during the early growth stages, but such origin is seemingly incompatible with the excellent preservation of bone within the concretions. It is noteworthy, however, that descriptions of bone destruction by adipocere are confined to freshwater occurrences and might not apply in marine environments where abundant calcium is available.

$\delta^{18} \mathrm{O}$ values of the dolomitic matrix of the Huron Member concretions are only a few per mil lower than values for unaltered marine carbonates and are compatible with formation in marine pore fluid at low but progressively increasing temperatures. $\delta^{18} \mathrm{O}$ values of the recrystallized remnant calcite cores and most calcite veins and vugs in the concretions are low and uniform and most likely reflect late-stage recrystallization and growth at moderate temperatures in the presence of formation fluid with a $\delta^{18} \mathrm{O}$ value reasonably close to that of seawater. Because concretion growth and replacement processes are complex and appear to occur at different stages under varying conditions, we agree with Hodgson (1966) that paleoenvironmental conclusions derived from stable isotopic data of diagenetic carbonates must be viewed with skepticism.

\section{REFERENCES}

Allen, J.R.L., and Friend, P.F., 1968, Deposition of the Catskill facies, Appalachian region: With notes on some other Old Red Sandstone basins: Geol. Soc. America Special Paper 106, p. 21-74.

Baker, P.A., and Kastner, Miriam, 1981, Constraints in the formation of sedimentary dolomite: Science, $v$. 213, p. 214-216.

Barrell, Joseph, 1913, The Upper Devonian delta of the Appalachian geosyncline: Part 1. The delta and its relations to the interior sea: Am. Jour. Sci., v. 36 (4th ser.), p. 429-472.

Bergmann, Werner, 1963, Geochemistry of lipids, in Breger, I.A., ed., Organic Geochemistry: New York, Pergamon, p. 503-542.

Berner, R.A., 1968, Calcium carbonate concretions formed by the decomposition of organic matter: Science, v. 159, p. 195-197.

Bownocker, J.A., 1965, Geologic Map of Ohio, 1:500,000: Ohio Geological Survey.

Broadhead, R.F., Kepferle, R.C., and Potter, P.E., 1980, Lithologic descriptions of cores and exposures of Devonian shale and associated strata in Ohio along Lake Erie: U.S. Geological Survey Open-File Rept. 80-719, 96 p.

Brown, R.W., 1954, How does cone-in-cone become emplaced?: Am. Jour. Sci., v. 252, p. 372-376.

Burruss, R.C., and Goldstein, R.H., 1980, Time and temperature of hydrocarbon migration: fluid inclusion evidence from the Fayetteville Formation, NW Arkansas: Geol. Soc. America Abs. with Prgms., v. 12, p. 396.

Carroll, Dorothy, 1970, Clay minerals: A guide to their $\mathrm{x}$-ray identification: Geol. Soc. America Spec. Paper, v. $126,80 \mathrm{p}$.

Chave, K.E., 1952, A solid solution between calcite and dolomite: Jour. Geology, v. 60, p. 190-192.

Cheney, E.S., and Jensen, M.L., 1965, Stable carbon isotopic composition of biogenic carbonates: Geochim. et Cosmochim. Acta, v. 29, p. 1331-1364.

Choquette, P.W., and James, N.P., 1987, Diagenesis \#12. Diagenesis in limestones-3. The deep burial environment: Geoscience Canada, v. 14, no. 1, p. 3-35.

Clayton, R.N., Friedman, Irving, Graf, D.L., Mayeda, T.K., Meents, W.F., and Shimp, N.F., 1966, The origin of saline formation waters: Jour. Geophys. Res., v. 71, p. 3869-3882. 
Clayton, R.N., O'Neil, J.R., and Mayeda, T.K., 1972, Oxygen isotope exchange between quartz and water: Jour. Geophys. Res., v. 77, p. 3057-3067.

Clifton, H.E., 1957, The carbonate concretions of the Ohio Shale: Ohio Jour. Sci., v. 57(2), p. 114-124.

Coleman, M.L., and Raiswell, R., 1981, Carbon, oxygen, and sulfur isotope variations in concretions from the Upper Lias of N.E. England: Geochim. et Cosmochim. Acta., v. 45 , p. $329-340$.

Cooke, D.J., 1976, A paleomagnetic study of the concretions of the Huron shale: Unpub. BS thesis, Dept. Geol. and Mineralog., Ohio State University, Columbus, $\mathrm{OH}, 36 \mathrm{p}$.

Craig, Harmon, 1957, Isotopic standards for carbon and oxygen and correction factors for mass-spectrometric analysis of carbon dioxide: Geochim. et Cosmochim. Acta, v. 12, p. 133-149.

Daly, R.A., 1900, "The calcareous concretions of Kettle Point, Lambton County, Ontario": Jour. Geology, v. 8, p. 135-150.

Dawson, Sir J.W., 1894, The Canadian ice age: New York, The Scientific Publishing Company, 301 p.

Dean, Bashford, 1902, The preservation of muscle-fibres in sharks of the Cleveland Shale: Am. Geologist, v. 30 , p. 273-278.

Degens, E.T., and Epstein, Samuel, 1964, Oxygen and carbon isotope ratios in coexisting calcites and dolomites from recent and ancient sediments: Geochim. et Cosmochim. Acta, v. 28, p. 23-44.

Degens, E.T., Pierce, W.D., and Chilingar, G.V., 1962, Origin of petroleum-bearing fresh-water concretions of Miocene age: Am. Assoc. Petrol. Geologists Bull., v. 62 , p. $1522-1527$.

Dennison, J.M., and Textoris, D.A., 1977, Tioga bentonite time-marker associated with Devonian shales in Appalachian basin, in Schott, G.L., Overbey, W.K., Hunt, A.E., and Komar, C.A., eds., First Eastern Gas Shales Symposium: Morgantown Energy Research Center, ERDA, p. 113-129.

Dix, G.R., and Mullins, H.T., 1987, Shallow, subsurface growth and burial alteration of Middle Devonian calcite concretions: Jour. Sed. Petrology, v. 57, p. 140-152.

Epstein, Samuel, Buchsbaum, R., Lowenstam, H.A., and Urey, H.C., 1953, Revised carbonate-water isotopic temperature scale: Geol. Soc. America Bull., v. 64, p. 1315-1326.

Epstein, Samuel, Graf, D.L., and Degens, E.T., 1964, Oxygen isotope studies on the origin of dolomites, in Craig, Harmon, Miller, S.L., Wasserburg, G.J., eds., Isotopic and cosmic chemistry: Amsterdam, NorthHolland, p. 169-180.

Epstein, A.G., Epstein, J.B., and Harris, L.D., 1977, Conodont color alteration-an index to organic metamorphism: U.S. Geol. Survey Prof. Paper 995, $27 \mathrm{p}$.

Foreman, H.P., 1959, A new occurrence of Devonian radiolaria in calcareous concretions of the Huron Member of the Ohio Shale: Jour. Paleontology, v. 33, p. 76-80.
Friedman, Irving, and O'Neil, J.R., 1977, Compilation of stable isotope fractionation factors of geochemical interest: U.S. Geol. Survey Prof. Paper 440-KK.

Galimov, E.M., Girin, Yu. P., and Vernadskiy, V.I., 1968, Variation in the isotopic composition of carbon during the formation of carbonate concretions: Geochem. International, v. 5, p. 178-182.

Girin, Yu. P., 1967, Geochemical stages during diagenesis of middle Jurassic sediments of the High Caucasus: Geochem. International, v. 4, p. 1146-1158.

Grim, R.E., 1968, Clay Mineralogy: New York, McGrawHill, $596 \mathrm{p}$.

Guimarāes, Djalma, 1964, Geologia do Brazil: Divisao de Fomento da Producao Mineral: Mem. No. 1, 674 p. Rio de Janeiro, Brazil.

Hall, W.E., and Friedman, Irving, 1969, Oxygen and carbon isotopic composition of ore and host rock of selected Mississippi Valley deposits: U.S. Geol. Survey Prof. Paper 650-C, p. C140-C148.

Hass, W.H., 1956, Age and correlation of the Chattanooga Shale and the Maury Formation: U.S. Geol. Survey Prof. Paper 286, 47 p.

Hathaway, J.C., and Degens, E.T., 1969, Methanederived marine carbonates of Pleistocene age: Science, v. 165 , p. $690-692$.

Hennessy, Joel, and Knauth, L.P., 1985, Isotopic variations in dolomite concretions from the Monterey Formation, California: Jour. Sed. Petrology, v. 55, p. 120-130.

Hodgson, W.A., 1966, Carbon and oxygen isotope ratios in diagenetic carbonates from marine sediments: Geochim. et Cosmochim. Acta, v. 30, p. 1223-1233.

Hoover, K.V., 1960, Devonian-Mississippian shale sequence in Ohio: Ohio Geol. Survey Inf. Cir. no. 27, Columbus, Ohio $154 \mathrm{p}$.

Hosterman, J.W., and Whitlow, S.I., 1983, Clay mineralogy of Devonian shales in the Appalachian basin: U.S. Geol. Survey Prof. Paper 1298, 31 p.

Hower, John, Schmittroth, L.A., Perry, E.C., and Mowatt, T.C., 1964, X-ray spectrographic major constituent analysis in undiluted silicate rocks and minerals: Geol. Soc. America Spec. Paper 82, p. 96-97.

Hudson, J.D., 1978, Concretions, isotopes, and the diagenetic history of the Oxford Clay (Jurassic) of central England: Sedimentology, v. 25, p. 339-370.

Hudson, J.D., and Friedman, Irving, 1976, Carbon and oxygen isotopes in concretions: relationship to porewater changes during diagenesis, in Cadek, J., and Paces, T., eds., Proc. Internat. Symposium on Water/ Rock interaction, Czechoslovakia, 1974: p. 331-339. Geol. Survey, Prague.

Hyde, C., and Landy, R.A., 1966, Whewellite from septarian concretions near Milan, Ohio: Am. Mineralogist, v. 51, p. 228-229.

Irwin, Hilary, Curtis, Charles, and Coleman, Max, 1977, Isotopic evidence for source of diagenetic carbonates formed during burial of organic-rich sediments: Nature, v. 269, p. 209-213. 
Jackson, M.L., 1973, Soil chemical analysis-advanced course: Dept. Soil Science, Univ. of Wisconsin, Madison, Wisconsin.

Keith, M.L., and Weber, J.N., 1964, Carbon and oxygen isotopic composition of selected limestones and fossils: Geochim. et Cosmochim. Acta, v. 28, p. 1787-1816.

Land, L.S., 1980, The isotopic and trace element geochemistry of dolomite: the state of the art: SEPM Spec. Pub. No. 28, p. 87-110.

Lawrence, J.R., and Geiskes, J.M., 1981, Constraints on water transport and alteration in the oceanic crust from the isotopic composition of pore water: Jour. Geophys. Res., v. 86, p. 7924-7934.

Lewis, T.L., and Schwietering, J.F., 1971, Distribution of the Cleveland black shale in Ohio: Geol. Soc. America Bull., v. 82, p. 3477-3482.

Lippmann, F., 1955, Ton, geoden und minerale des Barreme von Hoheneggelsen: Geol. Rundschau, v. 43, p. 475-503.

McCrea, J.M., 1950, On the isotopic chemistry of carbonates and a paleotemperature scale: Jour. Chem. Physics, v. 18, p. 849-857.

Maynard, J.B., 1981, Carbon isotopes as indicators of dispersal pattern in Devonian-Mississippian shales of the Appalachian basin: Geology, v. 9, p. 262-265.

Müller, German, 1967, Diagenesis in argillaceous sediments, in Larsen, Gunnar, and Chilingar, G.V., eds., Diagenesis in Sediments: New York, Elsevier Publishing Co., p. 127-177.

Murata, K.J., Friedman, Irving, and Cremer, Marcelyn, 1972, Geochemistry of diagenetic dolomites in Miocene marine formations of California and Oregon: U.S. Geol. Survey Prof. Paper 724-C, 12 p.

Murphy, J.L., 1973, Protosalvinia (Foerstia) zone in the Upper Devonian sequence of eastern Ohio, northwestern Pennsylvania, and western New York: Geol. Soc. America Bull., v. 84, p. 3405-3410.

Nelson, B.W., 1955, Mineralogy and stratigraphy of the pre-Berea sedimentary rocks exposed in northern Ohio: Doctoral thesis, Urbana, University of Illinois, $104 \mathrm{p}$.

Newberry, J.S., 1873, Geological structure of Ohio-Devonian System: Ohio Geol. Survey Rept., v. 1, p. 140-167.

Oertel, Gerhard, and Curtis, C.D., 1972, Clay-ironstone concretion preserving fabrics due to progressive compaction: Geol. Soc. America Bull., v. 83, p. 2597-2606.

O'Neil, J.R., Clayton, R.N., and Mayeda, T.K., 1969, Oxygen isotope fractionation in divalent metal carbonates: Jour. Chem. Physics, v. 51, p. 5547-5558.

Raiswell, R., 1971, The growth of Cambrian and Liassic concretions: Sedimentology, v. 17, p. 147-171.

1976, The microbiological formation of carbonate concretions in the upper Lias of NE England: Chem. Geology, v. 18, p. 227-244.

Romankiw, L.A., Hatcher, P.G., and Roen, J.B., 1987, Evidence of land plant affinity for the Devonian microfossil Protosalvinia (Foerstia). Submitted to Lethaia.

Romer, A.S., 1971, Vertebrate paleontology: Chicago, University of Chicago Press, 468 p.

Sass, Eytan, and Kolodny, Yehoshua, 1972, Stable isotopes, chemistry, and petrology of carbonate concretions (Mishash Formation, Israel): Chem. Geology, v. 10, p. 261-286.

Schopf, J.M., and Schwietering, J.F., 1970, The Foerstia zone of the Ohio and Chattanooga Shales: U.S. Geol. Survey Bull. 1294 H, p. H1-H14.

Schwietering, J.F., 1977, Preliminary model of Catskill delta in West Virginia, in Schott, G.L., Overbey, W.K., Hunt, A.E., and Komar, C.A., eds., First Eastern Gas Shales Symposium, Morgantown Energy Research Center, ERDA, p. 142-152.

Sharma, T., and Clayton, R.N., 1965, Measurement of $\mathrm{O}^{18} / \mathrm{O}^{16}$ ratios of total oxygen of carbonates: Geochim. et Cosmochim. Acta, v. 29, p. 1247-1353.

Siegel, D.I., Chamberlain, S.C., and Dossert, W.P., 1987, The isotopic and chemical evolution of mineralization in septarian concretions: Evidence for episodic paleohydrogeologic methanogenesis: Geol. Soc. America Bull., v. 99, p. 385-394.

Sondheimer, Ernest, Dence, W.A., Mattick, L.R., and Silverman, S.R., 1966, Composition of combustible concretions of the alewife, Alosa pseudoharengus: Science, v. 152, p. 221-223.

Stauffer, C.R., Hubbard, G.D., and Bownocker, J.A., 1911, Geology of the Columbus Quadrange: Ohio Geol. Survey Bull., v. 14, 133 p.

Stauffer, C.R., 1944, The geological section at the Limestone Mine, Barberton, Ohio: Am. Jour. Sci., v. 242, p. 251-271.

Taylor, H.P., Jr., and Epstein, Samuel, 1962, Relationship between ${ }^{18} \mathrm{O} /{ }^{16} \mathrm{O}$ ratios in coexisting minerals in igneous and metamorphic rocks. Part 1: Principles and experimental results: Geol. Soc. America Bull., v. 73 , p. $461-480$.

Tourtelot, H.A., and Rye, R.O., 1969, Distribution of oxygen and carbon isotopes in fossils of Late Cretaceous age, western interior region of North America: Geol. Soc. America Bull., v. 80, p. 1903-1922.

Weber, J.N., Williams, E.G., and Keith, M.L., 1964, Paleoenvironmental significance of carbon isotopic composition of siderite nodules in some shales of Pennsylvanian age: J. Sed. Petrology, v. 34, p. 814-818.

Weeks, L.G., 1957, Origin of carbonate concretions in shales, Magdalena Valley, Colombia: Geol. Soc. America Bull., v. 68, p. 95-102.

Weigelt, Johannes, 1935, Some remarks on the excavations in the Geisel Valley: Research and Progress, v. 1, p. 155-159.

Wells, J.W., 1947, Provisional paleoecological analysis of the Devonian rocks of the Columbus region: Ohio Jour. Sci., v. 47(3), p. 119-126.

Westgate, L.G., 1926, Geology of Delaware County: Ohio Geol. Survey Bull., v. 30, 147 p. 
Winder, C.G., 1966, Conodont zones and stratigraphic variability in Upper Devonian rocks, Ontario: Jour. Paleontology, v. 40, p. 1275-1293.

Winslow, M.R., 1962, Plant spores and other microfossils from Upper Devonian and Lower Mississippian- rocks of Ohio: U.S. Geol. Survey Prof. Paper 364, 93 p.

Zangerl, Rainer, Woodland, B.G., Richardson, E.S., and Zachry, D.L., Jr., 1969, Early diagenetic phenomena in the Fayetteville black shale (Mississippian) of Arkansas: Sed. Geology, v. 3, p. 87-119. 




\section{Perlodicals}

Earthquakes \& Volcanoes (issued bimonthly).

Preliminary Determination of Epicenters (issued monthly).

\section{Technical Books and Reports}

Professional Papers are mainly comprehensive scientific reports of wide and lasting interest and importance to professional scientists and engineers. Included are reports on the results of resource studies and of topographic, hydrologic, and geologic investigations. They also include collections of related papers addressing different aspects of a single scientific topic.

Bulletins contain significant data and interpretations that are of lasting scientific interest but are generally more limited in scope or geographic coverage than Professional Papers. They include the results of resource studies and of geologic and topographic investigations; as well as collections of short papers related to a specific topic.

Water-Supply Papers are comprehensive reports that present significant interpretive results of hydrologic investigations of wide interest to professional geologists, hydrologists, and engineers. The series covers investigations in all phases of hydrology, including hydrogeology, availability of water, quality of water, and use of water.

Circulars present administrative information or important scientific information of wide popular interest in a format designed for distribution at no cost to the public. Information is usually of short-term interest.

Water-Resources Investigations Reports are papers of an interpretive nature made available to the public outside the formal USGS publications series. Copies are reprouluced on request unlike formal USGS publications, and they are also available for public inspection at depositories indicated in USGS catalogs.

Open-File Reports include unpublished manuscript reports, maps, and other material that are made available for public consultation at depositories. They are a nonpermanent form of publication that may be cited in other publications as sources of information.

\section{Maps}

Geologic Quadrangle Maps are multicolor geologic maps on topographic bases in $71 / 2$ - or 15-minute quadrangle formats (scales mainly $1: 24,000$ or $1: 62,500$ ) showing bedrock, surficial, or engineering geology. Maps generally include brief texts; some maps include structure and columnar sections only.

Geophysical Investigations Maps are on topographic or planimetric bases at various scales; they show results of surveys using geophysical techniques, such as gravity, magnetic, seismic, or radioactivity, which reflect subsurface structures that are of economic or geologic significance. Many maps include correlations with the geology.

Miscellaneous Investigations Series Maps are on planimetric or topographic bases of regular and irregular areas at various scales; they present a wide variety of format and subject matter. The series also includes $71 / 2$-minute quadrangle photogeologic maps on planimetric bases which show geology as interpreted from aerial photographs. Series also includes maps of Mars and the Moon.
Coal Investigations Maps are geologic maps on topographic or planimetric bases at various scales showing bedrock or surficial geology, stratigraphy, and structural relations in certain coal-resource areas.

Oil and Gas Investigations Charts show stratigraphic information for certain oil and gas fields and other areas having petroleum potential.

Miscellaneous Field Studies Maps are multicolor or black-andwhite maps on topographic or planimetric bases on quadrangle or irregular areas at various scales. Pre-1971 maps show bedrock geology in relation to specific mining or mineral-deposit problems; post-1971 maps are primarily black-and-white maps on various subjects such as environmental studies or wildemess mineral investigations.

Hydrologic Investigations Atlases are multicolored or black-andwhite maps on topographic or planimetric bases presenting a wide range of geohydrologic data of both regular and irregular areas; principal scale is $1: 24,000$ and regional studies are at $1: 250,000$ scale or smaller.

\section{Catalogs}

Permanent catalogs, as well as some others, giving comprehensive listings of U.S. Geological Survey publications are available under the conditions indicated below from the U.S. Geological Survey, Books and Open-File Reports Section, Federal Center, Box 25425, Denver, CO 80225. (See latest Price and Availability List.)

"Publications of the Geological Survey, 1879-1961" may be purchased by mail and over the counter in paperback book form and as a set of microfiche.

"Publications of the Geological Survey, 1962-1970" may be purchased by mail and over the counter in paperback book form and as a set of microfiche.

"Publications of the U.S. Geological Survey, 1971-1981" may be purchased by mail and over the counter in paperback book form (two volumes, publications listing and index) and as a set of microfiche.

Supplements for 1982, 1983, 1984, 1985, 1986, and for subsequent years since the last permanent catalog may be purchased by mail and over the counter in paperback book form.

State catalogs, "List of U.S. Geological Survey Geologic and Water-Supply Reports and Maps For (State)," may be purchased by mail and over the counter in paperback booklet form only.

"Price and Availability List of U.S. Geological Survey Publications," issued amually, is available free of charge in paperback booklet form only.

Selected coples of a monthly catalog "New Publications of the U.S. Geological Survey" available free of charge by mail or may be obtained over the counter in paperback booklet form only. Those wishing a free subscription to the monthly catalog "New Publications of the U.S. Geological Survey" should write to the U.S. Geological Survey, 582 National Center, Reston, VA 22092.

Note.--Prices of Government publications listed in older catalogs, announcements, and publications may be incorrect. Therefore, the prices charged may differ from the prices in catalogs, announcements, and publications. 


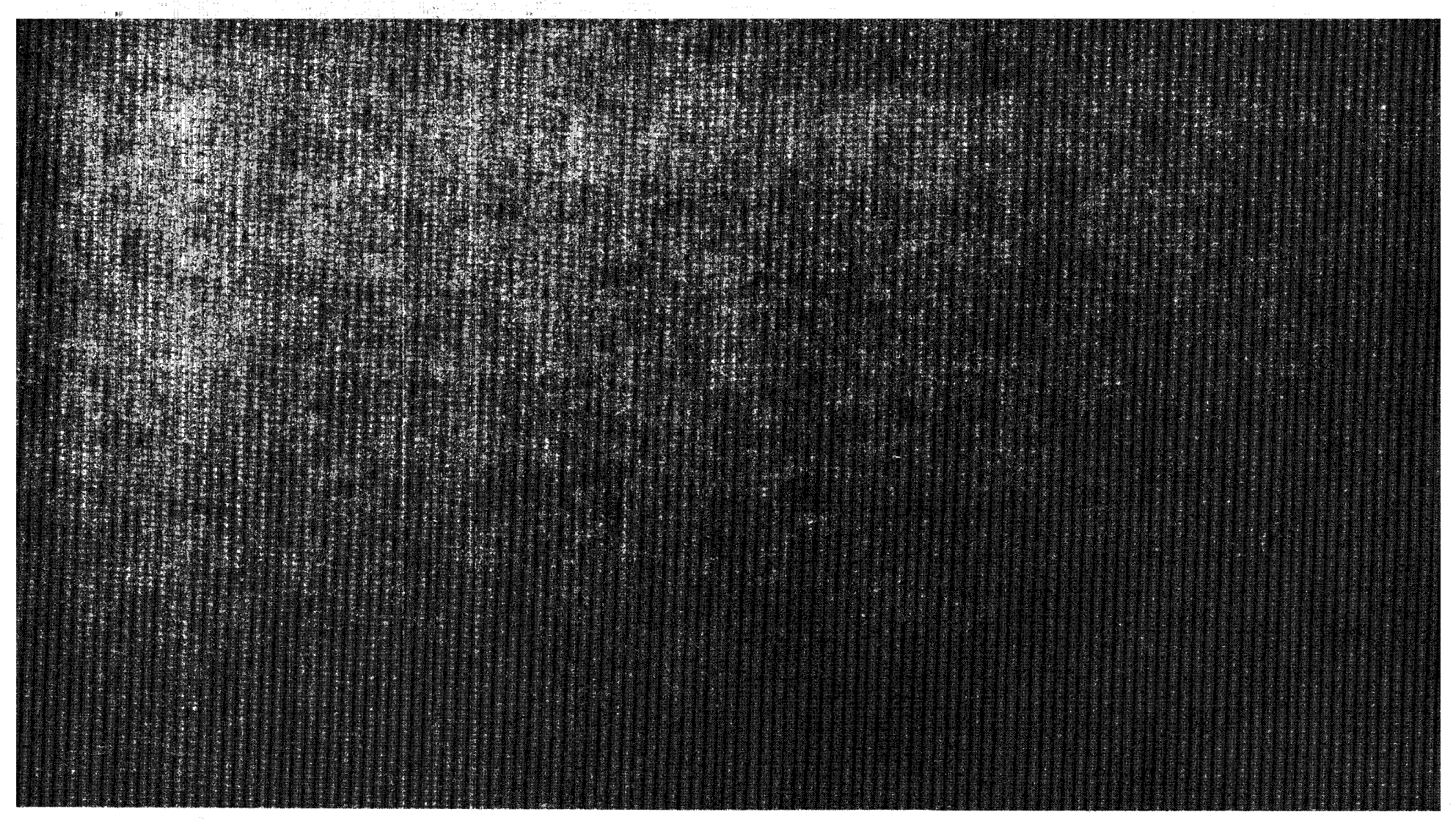

